Sugeng, E. S., Varma, N., \& Smith, Z. A. (2019). Evaluation of the Normalisasi Policy in Jakarta, Indonesia Using System Dynamics. Landscape Architecture Frontiers, 7(3), 78-93. https://doi.org/10.15302/J-LAF-1-020005

\section{基于系统动力学的印度尼西亚 雅加达市 “河流正常化” 政策评估 EVALUATION OF THE NORMALISASI POLICY IN JAKARTA, INDONESIA USING SYSTEM DYNAMICS}

黄志隆

新加坡国立大学住宿型学院本科在读

纳瓦鲁恩 ·瓦尔马

新加坡国立大学住宿型学院研究员 (讲师)、校外课程副主任

扎卡里 $\cdot$ 亚伦 $\cdot$ 史密斯

新加坡新跃社科大学副讲师

Edwin Setiadi SUGENG

Undergraduate student of Residential College 4, National University of Singapore

Navarun VARMA*

Fellow (Lecturer) and Assistant Director of External Programmes at Residential College 4, National

University of Singapore

\section{Zachary Aaron SMITH}

Associate Lecturer at Singapore University of Social Sciences

*Corresponding Author

Address: 6 College Avenue East \#BI-01, |386|4, Singapore

Email: navarun@nus.edu.ss
https://doi.org/10.15302/J-LAF-1-020005 收稿时间 RECEIVED DATE/ 2019-06-03 中图分类号/ N941.3, TV851, P331.1 文献标识码/A
摘要

洪涝、干旱及水体污染等迫切问题暴露了印 度尼西亚雅加达市的治理危机。尽管洪涝问题已 经上升到政治层面, 当地政府也正在推动河岸景 观的改善, 但雅加达的公共政策仍未厘清供水不 足与洪涝问题之间的复杂联系。

早在1872年, 雅加达的洪涝问题就已非常显 著。随后出现了多次重大洪涝灾害, 最近一次发 生于2015年。当地政府制定了多项政策来解决这 一难题, 新近提出的 “河流正常化” 政策即为其 中一项。其旨在提高河流泄洪能力, 避免暴雨期 间河水泛滥, 具体措施包括取缔河岸地区的非正 规居住点、拓宽河道和运河宽度及疏浚河床。但 不少学者对这项政策持批判态度，技术官僚性过 强是弊病之一, 以开发流域基础设施为名借机引 资为其二。此外，该政策也未顾及非正规居住点 居民的利益，难以促进建立兼具包容性与韧性的 社会 - 水文系统。

本研究借助系统动力学模型, 针对雅加达的 洪涝问题, 剖析了社会和水文 - 地貌因素间的相 互作用，对当前用以改善洪涝问题、预防潜在风 险的 “河流正常化” 政策进行了评估, 并进一步 对两类不同的洪水治理政策一一提升疏浚成效和 综合水景政策进行了检验和对比，结果表明：尽 管前者可在短期之内实现较高的效益且实施难度 较小, 后者却能够更加系统地应对雅加达的洪涝 问题以及未来的气候风险, 为城市带来更加持久 的㓞性。但综合水景政策在实施过程中既需要以 多中心治理制度为保障, 也需要依靠边界组织来 推动不同治理层面各行为主体的积极参与。

\section{关键词}

洪水; 雅加达; “河流正常化”政策; 系统动力 学; 社会 - 水文系统; 疏浚

\section{ABSTRACT}

Governance deficit in Jakarta, Indonesia is often associated to its pressing issues of too much, too little, and too dirty water. Although flood has become an important political issue and the government is pushing a landscape change in the riverbank areas, the public policy in Jakarta has yet to comprehend the complex linkages between the gap in water provisioning and flooding

Flood is one major issue that has affected Jakarta since as early as 1872 . Subsequently, major flood events occurred with the most recent being in 2015. To solve this problem, the government has implemented several policies, with the most recent one named as "Normalisasi." This policy focuses on increasing the flow capacity of the river to prevent it from overflowing during heavy rain events. Under this policy, the government claims eviction of informal settlements from the riverbank areas; widening rivers and canals; and dredging the river beds. Many scholars have criticized the overly technocratic framing of this policy, its covert agenda for attracting investments in infrastructure development in catchment areas, lack of empathy towards informal settlers, along with lack of vision for an inclusive and resilient socio-hydrological system.

This study uses system dynamics modeling to illustrate the interplay of social and hydrogeomorphological factors leading to Jakarta's vulnerability to flooding and to evaluate the policy response of Normalisasi against this vulnerability and future risk scenarios. The model is further used to test and compare two categories of policy strategies of increasing dredging efficacy and an integrated waterscape policy. Though the former seemed cost-efficient in short term and less complex in terms of governance, the latter the Jakarta flooding issue more holistically with future climate risks. However, implementation of such an integrated waterscape policy requires the institutionalization of polycentric governance and also needs a boundary organization to increase participation of diverse actors across governance levels.

\section{KEY WORDS}

Floods: Jakarta: Normalisasi: System Dynamics: Social-Hydrological System; Dredging will help in long-term resilience as it considers

编辑 王颖 翻译 肖杰 王颖

EDITED BY WANG Ying TRANSLATED BY XIAO Jie WANG Ying 


\section{1 透过 “沉降城市” 审视亚洲城市化进程与水资源问题}

当全球即将迎来“亚洲世纪”，亚洲自身也正面临着越来越严 峻的发展问题——城市愈发拥挤、人口结构显著变化、水资源日益减 少、各类污染不断加剧、自然灾害频发, 气候变化亦为当地带来了更 多不确定因素。水对人类生存与社会经济发展至关重要, 但城市的可 持续发展往往受到洪涝、干旱和生态系统退化的威胁, 其根源则主要 在于治水不力 ${ }^{[1]-[3]}$ 。缺乏合理规划的扩张使得城市越发难以抵抗水文一气 象灾害, 与此同时, 气候变化也在加剧这类环境灾害的不确定性 ${ }^{[4[5]}$ 。

在整个亚洲的城市化背景下, 印度尼西亚的城市GDP以年均 $4.1 \%$ 的增速快速发展, 高于其他多个亚洲国家, 值得深入探究。2000 2010 年, 印度尼西亚的城市用地面积由 $8900 \mathrm{~km}^{2}$ 增长至 $10000 \mathrm{~km}^{2}$, 增幅为 历史之最。预计到 2025 年, 印度尼西亚 $68 \%$ 的人口将居住在城市中。 但由于发展规划不合理造成的交通拥堵、污染加剧及灾害频发等诸多 问题, 印度尼西亚的城市化水平每增加 $1 \%$ 仅能带动 $4 \%$ 的GDP增长, 远 低于多数邻国水平 ${ }^{[6]}$ 。

不同国家对城市地区的定义不尽相同, 人口数量或人口密度均可 作为评判依据 ${ }^{[7]}$ 。根据印度尼西亚中央统计局的标准, 如某地人口密 度、农业人口比例及城镇设施的可达性和可用性总分高于 10 , 即视为 城市地区 (表1 $)^{[8]}$ 。

雅加达的人口密度约为 15663 人 $/ \mathrm{km}^{2[9]}$, 农业人口占比仅为 $0.02 \%{ }^{[10]}$, 根据上述标准属城市地区。雅加达首都特区是印度尼西亚的 34 个省市 之一 ${ }^{[11]}$, 是该国最大的都市区 ${ }^{[12]}$, 城市化速度极快 ${ }^{[13]}$ 。2017年, 雅加达 的人口数量迅速增长到 1070 万 $^{[14]}$, 土地不足及人居环境管理缺失等问 题随之而来 ${ }^{[13]}$ 。

在雅加达的城市化进程中, 种植园被逐渐征用为居住区和工业 区, 回灌区域面积不断减少, 而为满足用水需求对地下水进行的过 度开采导致地下水位下降, 进而引发土地下沉 (通常称为 “地面沉

\section{Urbanization and Water Problems in Asia through the Lens of a Sinking City}

As the Asian century is unfolding, there is also a rise in concerns over denser cities, demographic changes, dwindling water resources, increasing pollution and disasters, along with the uncertainties over local impacts of climate change in the continent. Water is essential for existence of human settlements and their socio-economic development. However, the sustainable development of cities is threatened by flood, drought, and ecosystem degradation, which are mainly attributed to a failure of water governance ${ }^{[1] \sim[3]}$. The unplanned sprawls increase social vulnerability to hydro-meteorological disasters while the environmental risks associated with such hazards are becoming uncertain with climatic changes ${ }^{[4][5]}$.

In this context of urbanization in Asia, Indonesian cities are worth exploring as their GDP growth rate is about $4.1 \%$ per year, which is faster than many others in the continent. Indonesia witnessed its largest increase in absolute amount of urban land within a decade since 2000 , from $8,900 \mathrm{~km}^{2}$ to $10,000 \mathrm{~km}^{2}$. It is expected that $68 \%$ of Indonesia's population will be living in cities by 2025 . However, Indonesia is gaining only $4 \%$ of GDP growth for every $1 \%$ of urbanization, a rate which is much lower than many of its neighbors, due to congestion, pollution, and disasters resulting from inappropriate planning ${ }^{[6]}$.

The definition of urbanized areas differs from country to country. Some countries define urbanized areas based on the population, while some others incorporate population density ${ }^{[7]}$. The Central Statistics Bureau of Indonesia classifies an area to be urbanized if the total score for population density, percentage of farming-based household, and accessibility and availability to town facilities is more than 10 (Table 1$)^{[8]}$.

Based on the above criteria, Jakarta, with a population density of about 15,663 people per square kilometer ${ }^{[9]}$ and a percentage of farming-based household of only $0.02 \%{ }^{[10]}$, is classified as an urbanized area. The Capital Special Region Jakarta is one of the 34 provinces in Indonesia ${ }^{[11]}$. Being the capital region, it is the largest metropolitan area in Indonesia ${ }^{[12]}$ and undergoes a rapid urbanization ${ }^{[13]}$. A rapid growth of population, 10.7 million in $2017^{[14]}$, has contributed to issues like land scarcity and unregulated settlements ${ }^{[13]}$.

The process of urbanization in Jakarta included a conversion of plantation areas to household and industrial areas, a decrease of water recharge areas, and extensive groundwater use to meet water demand. Such processes are resulting in the decrease of groundwater levels, which is further triggering the sinking of Jakarta's land, or an issue commonly called as land subsidence. 
表1: 印度尼西亚城市地区划分评分标准

Table 1: Scoring criteria for urbanized areas in Indonesia

\begin{tabular}{|c|c|c|c|c|c|c|}
\hline \multicolumn{4}{|c|}{$\begin{array}{c}\text { 标准 } \\
\text { Criteria }\end{array}$} & \multicolumn{3}{|c|}{$\begin{array}{c}\text { 城镇设施的可达性和可用性 } \\
\text { Accessibility and availability of town facilities }\end{array}$} \\
\hline $\begin{array}{l}\text { 人口密度 }\left(\text { 人 } / \mathrm{km}^{2} \text { ) }\right. \\
\text { Population density } \\
\text { (people } / \mathrm{km}^{2} \text { ) }\end{array}$ & $\begin{array}{l}\text { 得分 } \\
\text { Score }\end{array}$ & $\begin{array}{l}\text { 农业人口占比 (\%) } \\
\text { Percentage of farming- } \\
\text { based household (\%) }\end{array}$ & $\begin{array}{l}\text { 得分 } \\
\text { Score }\end{array}$ & $\begin{array}{c}\text { 设施 } \\
\text { Facility }\end{array}$ & $\begin{array}{l}\text { 标准 } \\
\text { Criteria }\end{array}$ & $\begin{array}{l}\text { 得分 } \\
\text { Score }\end{array}$ \\
\hline$<500$ & 1 & $>70.00$ & 1 & \multirow{2}{*}{$\begin{array}{l}\text { 学校 } \\
\text { School }\end{array}$} & $\begin{array}{l}\text { 有或距离不大于 } 2.5 \mathrm{~km} \\
\text { Present or } \leqslant 2.5 \mathrm{~km}\end{array}$ & 1 \\
\hline $500 \sim 1,249$ & 2 & $50.00 \sim 69.99$ & 2 & & $\begin{array}{l}\text { 距离大于 } 2.5 \mathrm{~km} \\
>2.5 \mathrm{~km}\end{array}$ & 0 \\
\hline $1,250 \sim 2,499$ & 3 & $30.00 \sim 49.99$ & 3 & \multirow{2}{*}{$\begin{array}{l}\text { 集市、商店 } \\
\text { Market, shop }\end{array}$} & $\begin{array}{l}\text { 有或距离不大于 } 2 \mathrm{~km} \\
\text { Present or } \leqslant 2 \mathrm{~km}\end{array}$ & 1 \\
\hline $2,500 \sim 3,999$ & 4 & $20.00 \sim 29.99$ & 4 & & $\begin{array}{l}\text { 距离大于 } 2 \mathrm{~km} \\
>2 \mathrm{~km}\end{array}$ & 0 \\
\hline $4,000 \sim 5,999$ & 5 & $15.00 \sim 19.99$ & 5 & \multirow{2}{*}{$\begin{array}{c}\text { 影院、医院 } \\
\text { Cina, hospital }\end{array}$} & $\begin{array}{l}\text { 有或距离不大于 } 5 \mathrm{~km} \\
\text { Present or } \leqslant 5 \mathrm{~km}\end{array}$ & 1 \\
\hline $6,000 \sim 7,499$ & 6 & $10.00 \sim 14.99$ & 6 & & $\begin{array}{l}\text { 距离大于 } 5 \mathrm{~km} \\
>5 \mathrm{~km}\end{array}$ & 0 \\
\hline $7,500 \sim 8,499$ & 7 & $5.00 \sim 9.99$ & 7 & \multirow{2}{*}{$\begin{array}{l}\text { 旅馆、发廊 } \\
\text { Hotel, salon }\end{array}$} & $\begin{array}{l}\text { 有 } \\
\text { Present }\end{array}$ & 1 \\
\hline \multirow[t]{5}{*}{$>8,500$} & 8 & $<5.00$ & 8 & & $\begin{array}{l}\text { 无 } \\
\text { None }\end{array}$ & 0 \\
\hline & & & & \multirow{2}{*}{$\begin{array}{c}\text { 固定电话持有率 } \\
\text { Percentage of landline telephone }\end{array}$} & $\geqslant 8.00 \%$ & 1 \\
\hline & & & & & $<8.00 \%$ & 0 \\
\hline & & & & \multirow{2}{*}{$\begin{array}{c}\text { 无线电话持有率 } \\
\text { Percentage of radio telephone }\end{array}$} & $\geqslant 90.00 \%$ & 1 \\
\hline & & & & & $<90.00 \%$ & 0 \\
\hline
\end{tabular}

注释

表中距离为村庄或村政府到相应设施的距离。

NOTE

The distance is measured from the village / village office.

降” ）。地面沉降是导致雅加达洪涝灾害频发的已知原因之一 ${ }^{[15\}-[18]}$ 。

雅加达正在以每年1 $15 \mathrm{~cm}$ 的速度下沉，如今几乎半座城市都在海 平面之下 ${ }^{[19]}$ 。除雅加达外，曼谷、马尼拉和上海等其他亚洲城市也存在 不同程度的地面沉降问题 ${ }^{[20]}$ 。地面沉降是地壳表面标高降低、逐渐向地 心塌缩的一种现象, 主要由自然因素或人为因素导致的地下松散地层 不断压缩造成 ${ }^{[21]}$ 。其中, 自然因素 (如土壤类型) 可能会加快地面沉降 速度。例如, 当施以重力时, 含水量较高的土壤 (如粘土) 极易被压 缩, 沉降速率随即增大 ${ }^{[15522]}$ 。此外, 为满足施工期间或干旱时期的用水 需求而过度开采地下水也会加剧地面沉降 ${ }^{[15 \mid 161[21]}$

结合上述背景, 本文旨在探究雅加达复杂的城市洪涝问题, 剖析 社会和水文一地貌因素之间的相互作用对这一问题的影响，评估当前
Land subsidence has been known to make Jakarta more prone to flooding ${ }^{[15] \sim[18]}$.

Jakarta is sinking by $1 \sim 15 \mathrm{~cm}$ per year and almost half the city is now below the sea level ${ }^{[19]}$. However, Jakarta is not alone in Asia, three other cities - Bangkok, Manila, and Shanghai - share the same sinking or land subsidence phenomenon in varying rates ${ }^{[20]}$. Land subsidence is defined as a gradual movement of the Earth's surface towards the Earth's center. The movement occurs due to the compression of the Earth's subsurface elements ${ }^{[21]}$. The compression may occur due to both natural and human factors. First, natural factors, such as the type of soil, can speed up the subsidence. For example, soil with higher water content, such as clay, can easily be compressed when a heavyweight is imposed, which implies a higher rate of subsidence ${ }^{[15][22]}$. Second, human activities also exacerbate land subsidence, such as excessive groundwater extraction during construction or during droughts ${ }^{[15][16][21]}$.

Against this background, this paper aims to examine the complex issue of urban flooding in Jakarta to: provide an 


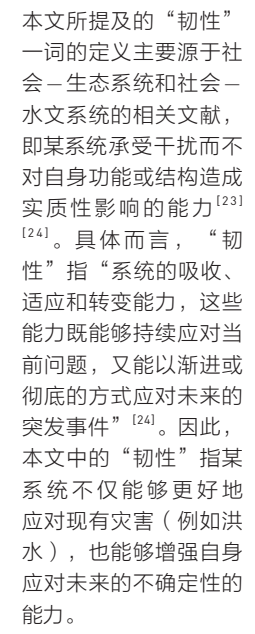

This paper takes the definition of "resilience" as used in socialecological systems and in social-hydrological systems literature the capacity of a system to absorb disturbance without substantially chent substantially challenging its function or structure ${ }^{2-212}$ Specifically, it is a set of "systemic absorptive, adaptive, and transformative capacities, which offers scope for its conceptualization cherion three dimensions persistence for now, and response for future contingencies in incremental or in radical ways.". ${ }^{[24]}$ Thus, resilience here means not only reducing vulnerability and increasing adaptability to existing hazards (such as floods), bu also enhancing a system's capability to cope with future uncertainties.

进行中的“河流正常 化” 政策

1. Normalisasi in progress
为缓解洪涝、预防潜在风险而提出的应对政策，并讨论能够提升城市 韧性 ${ }^{\circledR}$ 的对策。

\section{2 “河流正常化”政策——雅加达市的防洪举措}

早在1872年，雅加达的洪涝问题就已非常严峻。当降雨量达到 286mm时, 河水便会泛滥，继而引发洪涝灾害。此后，1977年、1994 年、1996年、1999年、2002年、2007年、2013年先后发生多起重大洪涝 灾害事件, 最近一次发生于 2015 年 ${ }^{[25]}$, 此次洪涝灾害导致 5 人丧生、约 23 万人撤离, 财产损失高达 1.5 万亿印度尼西亚卢比（约合 1 亿美元）。

为此, 雅加达政府实行了多项举措, 其中最新且最引人瞩目的即 为 “河流正常化”政策。该政策全称 “吉利翁河正常化项目”，旨在 通过提升河流 (尤其是吉利翁河) 的泄洪能力来解决雅加达的洪涝问 题 ${ }^{[26]}$, 具体举措包括疏浚河床、安装板桩及取缔河流沿岸的非正规居住 点 ${ }^{[27]}$ 。疏浚河床的目的是减少河道中的淤积物（图1); 安装板桩则是 为了加固河堤，并限制人们接近河流；取缔河流沿岸的非正规居住点

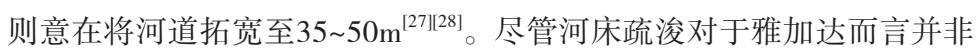
创新之举，但 “河流正常化” 政策引人了可大大提高疏浚效率的机械 化工具, 将机械化疏浚纳人项目策略制定之中, 以确保整个项目稳定 的经费来源 ${ }^{[29]}$

截至 2017 年, 全长 $33.69 \mathrm{~km}$ 的吉利翁河中已有 $16.38 \mathrm{~km}$ 的河段实施 了“正常化” 政策 ${ }^{[27]}$ 。尽管周边居民表示洪水致灾的频率有所降低，但 由于近期河道内的水量已与河堤持平，他们仍然担心河水再次泛滥 ${ }^{[27]}$ ${ }^{[30]}$ 。此外，被迁出的居民对新住处的安置条件也存在顾虑。已有部分迁 移居民对政府提供的公寓表示不满，其中地段偏远和租金过高是主要 原因 ${ }^{[31]}$ 。近来, 由于公众反对声音较大, 雅加达政府已叫停非正规居住 点居民的迁移，“河流正常化” 项目因此搁置 ${ }^{[32]}$ 。

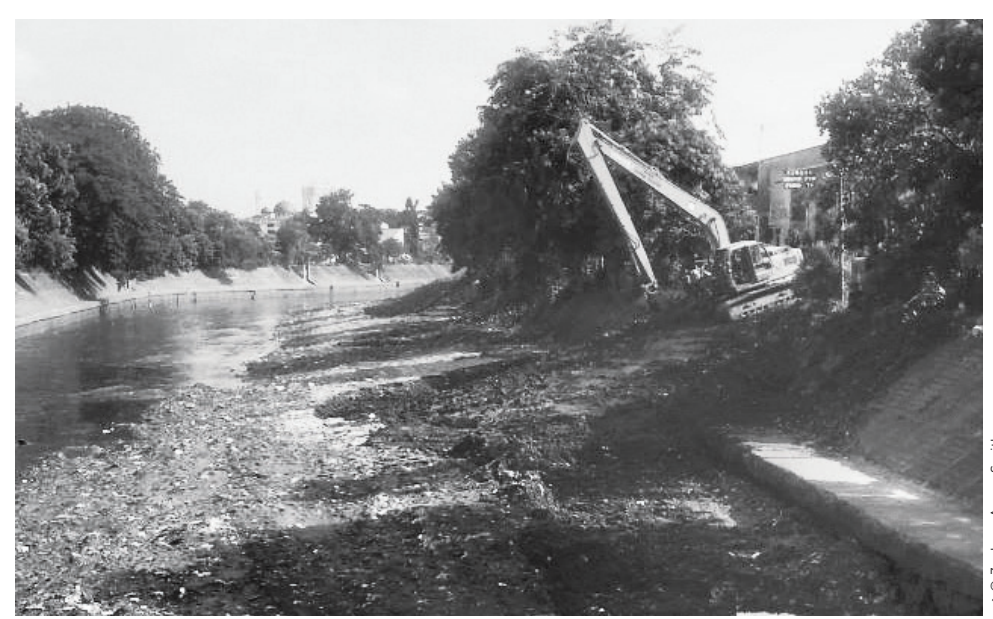

understanding of the interplay between social and hydrogeomorphological factors leading to the city's vulnerability to current flooding; evaluate current policy response to this vulnerability and future risk scenarios; and explore policy options for resilience ${ }^{(1)}$.

\section{Normalisasi - A Flood Control Initiative for Jakarta}

Flood is one major issue that has affected Jakarta since as early as 1872 . It occurred due to rainfall as high as 286 $\mathrm{mm}$, causing the rivers to overflow. Since then, several major flood events occurred in 1977, 1994, 1996, 1999, 2002, 2007, 2013 , and the most recent being in $2015^{[25]}$. In 2015, the flood claimed the lives of 5 people, the evacuation of about 230 thousand people, and financial loss amounting 1.5 trillion Indonesia rupiah (approximately USD 100 million).

As a response, the government of Jakarta implemented several initiatives, with the latest and the most ambitious one termed as "Normalisasi" (River Normalization), or formally called "Program Normalisasi Sungai Ciliwung" (Normalization Program for the Ciliwung River), aimed at increasing the channel capacity of rivers, especially the Ciliwung River, and resolving flooding in Jakarta ${ }^{[26]}$. To do so, the riverbeds are dredged, sheet piles are installed, and unregulated settlements along the riverbank are evicted ${ }^{[27]}$. The three activities have different targets: the dredging of riverbeds is to reduce the sediments and waste in the river (Fig. 1); the installation of sheet piles is to strengthen the river walls and limit access to the river; unregulated settlements are evicted to increase the width of the channel to about $35 \sim 50$ meters wide ${ }^{[27][28]}$. Although riverbed dredging is not new in Jakarta, Normalisasi provides mechanized tools for increasing the speed of dredging, introducing dredging as one of the strategies of the package, and ensuring continuous funding for the entire program ${ }^{[29]}$.

By 2017, $16.38 \mathrm{~km}$ out of $33.69 \mathrm{~km}$ of the Ciliwung River had undergone Normalisasi ${ }^{[27]}$. People residing in the vicinity of the river claimed that flood occurred less frequent. However, they are still worried about the possibilities of channel overflow, as the latest floods have caused the water to be as high as the channel walls ${ }^{[27][30]}$. Apart from such concerns, the evicted settlers have also raised concerns on the condition of their relocation settlements. The evicted people were discontent with their newly provided apartments due to a number of reasons among which remote location and high rents were primary $^{[31]}$. Recently, the government has responded to the public discontent and halted the evictions, through which the entire Normalisasi program has been stalled ${ }^{[32]}$. 
除了强降雨和肆意向河中倾倒垃圾之外, 雅加达的城市洪涝问题 也因地面沉降问题变得更加严峻 ${ }^{[15][33]}$ 。但地面沉降问题尚未在雅加达的 防洪减灾和水域综合治理政策中得到重视。随着城市化进程的推进, 更多人口将定居雅加达, 更多的水泥建筑也将拔地而起, 从而加剧地 面沉降 ${ }^{[13][15] \mid 22][34] ~}$

目前有学者对 “河流正常化” 政策的技术官僚性进行了批判 ${ }^{[26][35],}$ 指出该计划更长远的目标可能是进一步吸引基础设施建设投资, 进而带 动经济增长, 但不应以牺牲包容性城市景观为代价, 因为这将导致沿河 居民的边缘化。尽管雅加达的土地淹没问题有所缓解 ${ }^{[36]}$ (图2), 但地 面沉降的加剧 (图3) 可能进一步削弱城市应对洪涝灾害的能力 ${ }^{[15][16]}$ 。 这座城市的地面沉降与洪涝问题之间有着千丝万缕的联系, 需进一步探 究。此外, 受气候变化影响, 雅加达的降雨模式也可能发生改变 ${ }^{[34]}$, 因 此需提高整座城市的水管理韧性, 以应对未来的风险 ${ }^{[24]}$ 。

本文采用系统动力学方法 ${ }^{[37]}$ 来探究雅加达城市发展与水文一地貌 之间的动态复杂关系, 深人分析了城市防洪减灾能力不足的原因, 同 时就雅加达面临的现有挑战和未来风险评估了当前的 “河流正常化” 政策，继而检验并讨论了提高城市应对水问题韧性的对策。
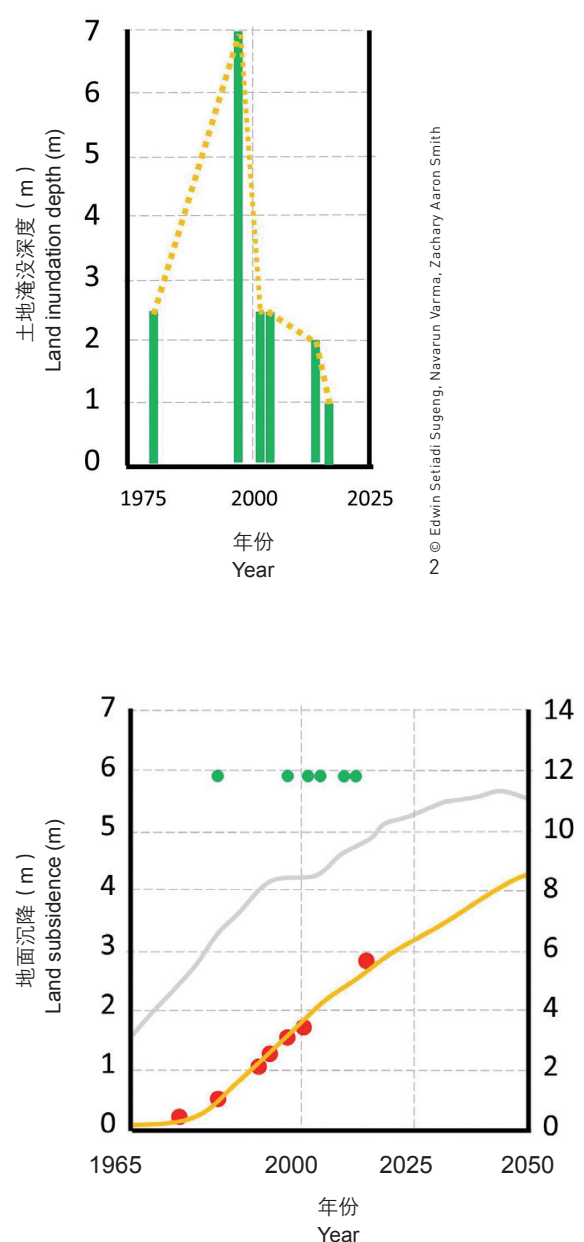

图例

主要洪水事件

Major flood events

地面沉降历史数据 Historical data of land subsidence

一 地面沉降趋势参考 ( 由DeltaRes软件生成) Reference mode of land subsidence (by DeltaRes)

一人口发展趋势 (由BPS软件生成) Population trend (by BPS)
Apart from heavy rainfalls and unregulated dumping of waste into the rivers, land subsidence is becoming another contributing factor to urban floods in Jakarta ${ }^{[15][33]}$. However, not only flood mitigation policy but also water governance in general in Jakarta has yet to focus on the issue of land subsidence. As urbanization continues, more people will settle in Jakarta and more concrete buildings are planned, which may just increase the sinking phenomenon ${ }^{[13][15][22][34]}$.

Scholars have criticized the technocratic framing of Normalisasi $^{[26][35]}$ for its agenda of attracting investments in infrastructure for economic growth and less focus on inclusive urban landscape, and thus leaving behind the issues of marginalized settlers of riverbanks. Although the land inundation level in Jakarta currently seems to be dropping ${ }^{[36]}$ (Fig. 2), the increasing land subsidence (Fig. 3) may further undermine the city's resilience to flooding ${ }^{[15][16]}$. The linkage between land subsidence and flooding in Jakarta context is complex and needs further study. Moreover, there are projections of changes in rainfall pattern of Jakarta owing to impacts of climate change ${ }^{[34]}$. This also requires a capacity enhancement in resilience of entire urban water management for future risks ${ }^{[24]}$.

This paper uses a system dynamics approach ${ }^{[37]}$ to explore the dynamic and complex relationships across urban development and hydro-geomorphology of Jakarta. It gives a rich understanding of the causes of the city's current vulnerability to riverine flooding, evaluates the current Normalisasi policy in terms of existing challenges and future risks, and goes ahead to test and discuss strategies for managing the city's resilience to water issues.

\section{Methodology: System Dynamics Modeling}

The system dynamics approach helps understand the dynamic complexity of real-world issues. It has been helpful to unbundle cause-effect and feedback structures across multiple levels at different interacting scales of society, governance, ecosystems, river channels, and even stakeholder views ${ }^{[38][39]}$. The approach is further useful to simulate different what-if scenarios and to identify leverage points for policy interventions for desirable system behaviors $^{[37]}$. This approach has been already practiced in understanding interactions in terms of pre-existing vulnerabilities, current pattern of hazards, and future risks from climatic changes in Asian urban contexts ${ }^{[4]}$.

In this paper, first, the technique of conceptual system modeling is used to grasp the dynamic complexity around Jakarta's vulnerability to flooding and policy responses. Information from secondary source was presented in the form of
Historical data of land inundation depth

3. Historical data of land subsidence lyellow line) and population lgrey linel 

因将在下文中阐述。

2) "A system refers to a set of interacting components forming complex whole, which is delineated by its boundaries, surrounded by its environment, and characterized by its structure and functions" ${ }^{[244]}$. Following this definition, system or subsystem in this paper refers to components or parts of human-water interaction within Jakarta. The paper (a) tink the linkages of the subsystems with the sea or coastline which would be explained as a limitation later.

\section{3 研究方法: 系统动力学模型}

系统动力学方法有助于理解现实问题的动态复杂性, 能够从社 会、治理、生态系统、河道甚至利益相关方的观点等多个相互关联的 尺度的不同层面上分析因果关系和反馈机制 ${ }^{[38][39]}$ 。该方法还可用于模拟 不同的假设情景，明确实现预期系统目标的政策干预抓手 ${ }^{[37]}$ 。目前，系 统动力学方法已被用于审视亚洲城市中既有的韧性危机、当前的灾害 发生规律, 以及气候变化所带来的潜在风险 ${ }^{[4]}$ 。

本文首先利用概念系统建模，了解雅加达洪涝频发的现状及其应 对政策之间的动态复杂关系。其次, 通过Vensim软件将二手文献中的 信息呈现为因果回路图 ${ }^{[37] \sim[39]}$ 。随后, 根据问题背景陈述中的文献综述 确定变量；任意两个变量之间的关系通过极性正负符号 “+”和 “_” 表示———+”代表因果之间呈正相关，“-”代表负相关；对于反馈 回路, 如果变化保持平衡, 则以 “B” 表示; 如果变化得到增强, 则以 “R” 表示。整个分析过程以单一来源的较短信息片段为起始, 进而将

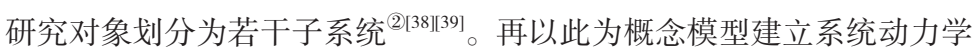
模型，模拟不同的情景，测试不同的政策对未来城市韧性的提升作 用 ${ }^{[37]}$ 。同时进行初步的成本一效益分析，并讨论政策带来的机遇和挑战。

\section{4 建模与分析}

\section{1 基于因果回路图的概念系统模型}

图4揭示了城市化进程、河道、土地沉降及地下水 4 个子系统之间 的因果关系和反馈关系, 这些子系统均对雅加达的城市洪涝问题有所 影响。本节将对这些因果回路图进行简要说明, 以帮助理解这一问题 的复杂背景 ${ }^{[39]}$

\subsection{1 城市化进程}

城市化进程子系统包含两个增强反馈回路 $\mathrm{R} 1$ 和 $\mathrm{R} 2$ 。如 $\mathrm{R} 1$ 所示, 雅 加达人口的增加刺激了更多的住房需求, 由此导致建成区面积增大 ${ }^{[40]}$ 。 不断扩大的建成区面积带动了经济增长 ${ }^{[41]}$, 进而吸引人们迁居城市, 城 市人口随之继续增加 ${ }^{[42]}$ 。在R2中, 物质条件 (包括建成区和建筑物 ${ }^{[43]}$ ) 是促进经济增长的重要因素 ${ }^{[41]}$; 经济增长需要更多的基础设施与之相匹 配，这将造成建成区面积的进一步扩大 ${ }^{[44]}$ 。

该子系统还包括 $\mathrm{R} 1$ 与 $\mathrm{R} 2$ 之外的其他因果关系。首先, 雅加达人口 的增长将加大城市用水量 ${ }^{[45]}$ 。其次，河水泛滥将造成更多的河岸居民被 迁移，这也是 “河流正常化” 政策的一部分 ${ }^{[46]}$ 。河岸居民的迁移所释放 的土地空间将吸引更多的投资，进而刺激经济增长 ${ }^{[35]}$ 。但与此同时，人 口的增加与作意的城市曼延又迫使部分人口只能居住在城市中有待开 causal loop diagrams (CLDs) ${ }^{[37]}$. The construction of the CLDs is done using the Vensim software ${ }^{[38][39]}$. Variables were selected from content review of the problem context. Linkages between any two variables were identified and assigned a polarity either "+" (indicating a positive correlation between the cause and effect) or "_" (indicating a negative correlation between the cause and effect); and feedback loops were identified and represented as " $B$ " if a change is balanced and " $R$ " if a change is reinforced ${ }^{[37]}$. Smaller segments of information from a single source were first analyzed as building blocks that ultimately formed part of subsystems ${ }^{(2)}$ of the problem ${ }^{[38][39]}$. This conceptual model is then used to come up with the system dynamics model to simulate different scenarios and also test different categories of strategies for future resilience in the context ${ }^{[37]}$. The policy testing is complemented with a preliminary cost-benefit analysis along with a discussion about the opportunities and challenges for policy.

\section{Modeling and Analysis}

\subsection{Conceptual System Model Using CLD}

Figure 4 shows the CLD that illustrates the causeeffect and feedback relations between different subsystems, namely Urbanization, River Channels, Land Subsidence, and Groundwater, influencing urban flooding in Jakarta. The CLD will be explained in parts to help in comprehending the complexity of the problem context ${ }^{[39]}$.

\subsubsection{Urbanization}

The Urbanization subsystem contains two Reinforcing Loops, $\mathrm{R} 1$ and R2. In R1, the population increase of Jakarta accelerates the need for more housing, hence, enlarging built are $\mathrm{a}^{[40]}$. The increasing built area will spur economic growt ${ }^{[41]}$, which in turn, will attract people to move to the city, hence leading to an increase in population ${ }^{[42]}$. In R2, the physical capital, which includes built area and buildings ${ }^{[43]}$, is a factor that helps accelerate economic growth ${ }^{[41]}$. With economic growth, more infrastructure will be needed, implying a larger built area ${ }^{[44]}$.

There are also causal relationships outside R1 and R2. First, as the population of Jakarta increases, the water consumption will increase correspondingly ${ }^{[45]}$. Second, the increase in overflow will result in the eviction of riverbank settlement, which is a part of Normalisasi ${ }^{[46]}$. The eviction of riverbank settlements will free up land spaces, attracting investments, then spurring economic growth $^{[35]}$. However, with the increasing population of Jakarta and the uncontrolled expansion of built area, some people will have to live in the remaining vacant spaces, such as the riverbank, 


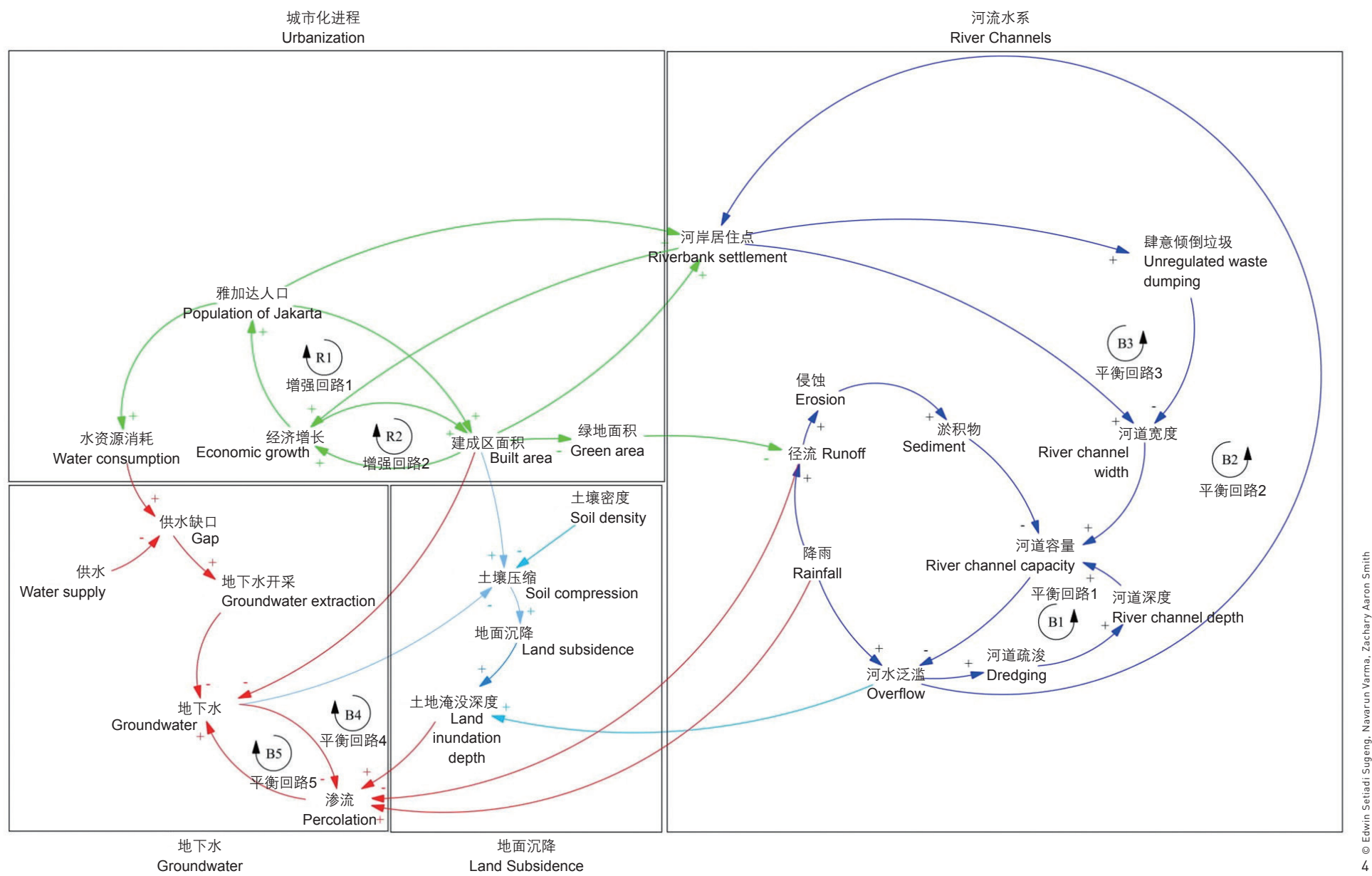

发的空置土地 (如河岸) 上, 致使河岸居住点数量又有所回升 ${ }^{[47]}$ 。第 三，建成区面积的增加也将导致绿地面积的减少 ${ }^{[15]}$ 。

\subsection{2 河道}

在河道子系统的因果回路图中，平衡回路1（B1）表明当洪水泛滥 时, 河床疏浚议题便会被提上日程 ${ }^{[26][48]}$, 疏浚后的河道深度加大，河道 容量增加 ${ }^{[26]}$, 进而使洪水泛滥日趋减少 ${ }^{[49]}$ 。在平衡回路2（B2）中, 河 水泛滥的频发将加速河岸居民的迁移 ${ }^{266[148]}$, 肆意向河中倾倒垃圾的现象 将随之减少 ${ }^{[4]}$ 。当河水流动的阻力减少, 河道容量将得到提升, 洪涝 现象也将减少 ${ }^{[26]}$ 。就平衡回路3（B3）而言，如果河岸居民因洪水泛滥 而被迁移 ${ }^{26[148]}$, 河道便有机会进行拓宽, 从而增加整体容量, 最终减少 洪溁 ${ }^{[26]}$ 。 hence increasing the number of riverbank settlements ${ }^{[47]}$. And third, the increase in built area will decrease the amount of green areas in Jakarta ${ }^{[15]}$.

\subsubsection{River Channels}

In the CLD for the River Channels, Balancing Loop 1 (B1) indicates that a rise in overflow may facilitate the will for a faster dredging ${ }^{[26][48]}$, a process which will deepen the channel, and hence, the channel capacity increases ${ }^{[26]}$, and in turn the amount of overflow reduced ${ }^{[49]}$. Regarding Balancing Loop 2 (B2), more overflow will accelerate the eviction of riverbank settlements ${ }^{[26][48]}$, bringing about a decrease in the unregulated waste dumping to the river ${ }^{[4]}$. With less dumping impeding the river flow, the channel capacity will increase while the overflow decreases ${ }^{[26]}$. For Balancing Loop 3 (B3), the increased overflow will cause more eviction of riverbank settlements ${ }^{[26][48]}$. Fewer riverbank settlements will in turn increase the channel width, which means an enlarged channel capacity and a decreased amount of overflow ${ }^{[26]}$. 
3) Land inundation dept is taken as proxy of extent of flooding

hazard and cause-effect and feedback structures contributing to its chior ef the vis a variable flooding.
在该子系统的其他因果关系中，由于绿地可以阻止水流汇人河道 中, 当绿地面积减少, 径流量便会增大。此外, 降雨强度越大, 径流 量也越大 ${ }^{[15][50]}$ 。过多的径流将引发河岸侵蚀, 使更多土壤和岩石沉积在 河道中，最终使河道的容量不断降低 ${ }^{[26][50]}$ 。

\subsection{3 地面沉降}

就地面沉降子系统而言，平衡回路4（B4）表明，随着土地淹没深 度 $^{3}$ 的增加, 土壤渗透率不断增大, 地下水位逐渐增高 ${ }^{[11][52]}$ 。而后土壤 压缩程度降低, 地面沉降幅度减小 ${ }^{[16]}$ 。由此可见, 地面沉降幅度与土地 淹没程度之间呈正相关 ${ }^{[17]}$ 。在平衡回路5（B5）中, 土壤中的地下水 含量越多, 土壤就越饱和, 土壤渗透率就越低, 地下水位的增幅也就 越小 ${ }^{[53]}$ 。

此外, 土壤密度 (即土壤质量与体积之比) 决定了土壤压缩的难 易程度。土壤密度越小, 其被压缩的可能性就越大 ${ }^{[54[55]}$ 。此外, 建筑物 重量的增加会加大土壤负荷, 因而城市开发区域越广, 土壤就越易被 压缩 ${ }^{[15]}$ 。另由于建筑施工过程中会进行地下水排水作业, 故建成区面积 越大, 地下水位下降就越快 ${ }^{[16]}$ 。同时, 土壤的渗透率也与降雨量密切相 关，降雨量越大，土壤渗透率就越高 ${ }^{[16]}$ 。

4.1.4 地下水

从地下水子系统中可以看出, 在用水量增加的同时, 如果没有充 足的水源补给, 那么地下水的供需差距就会越来越大，地下水的开采 也会愈演愈烈，导致地下水储备严重不足。但同时，地下水也可通过 渗流过程来补给 ${ }^{[15]}$ 。

\section{2 系统动力学模型}

基于图4所呈现的概念系统模型, 研究进一步建立了如图5所示的 系统动力学 (模拟) 模型。该模型细化了图4中的存量 (状态变量)、 流量 (速率变量) 以及影响流量的参量和辅助变量, 同时量化了各子 系统内部及彼此间的相互作用 ${ }^{[37][56]}$ 。此外, 在Vensim软件的辅助下, 该
For other types of causal relationship, as green areas help prevent water from running to the river, the decrease of green areas will cause an increase in runoff. Besides, the larger the rainfall intensity is, the more runoff there will be ${ }^{[15][50]}$. Moreover, the runoff may cause erosion, during which process soil and rocks may be deposited by the flow, hence increasing the amount of sediment. Finally, the accumulation of sediment decreases the channel capacity ${ }^{[26][50]}$.

\subsubsection{Land Subsidence}

Concerning the subsystem of Land Subsidence, it finds in Balancing Loop 4 (B4) that as the land inundation depth ${ }^{(3)}$ increases, there will be a higher percolation rate and a higher groundwater level ${ }^{[51][52]}$. The rise of groundwater will decrease the soil compression, which further reduces the level of land subsidence $^{[16]}$. Therefore, the land subsidence level is found to be positively related to the level of land inundation ${ }^{[17]}$. Balancing Loop 5 (B5) shows that the more groundwater the soil contains, the more saturated the soil is. With a higher soil saturation, the percolation rate will be lower, slowing down the groundwater increase as well ${ }^{[53]}$.

Besides, the soil density — the mass of soil divided by its volume - also affects the extent of soil compression. Thus, the soil with a lower density has a larger possibility to be compressed ${ }^{[54][55]}$. In addition, more urban development causes more soil compression, as the increase in buildings induces heavier load to the soil ${ }^{[15]}$; more built areas will result in less groundwater, as the groundwater will be drawn out for dewatering during the construction ${ }^{[16]}$. Meanwhile, the percolation rate is also affected by the rainfall, as with more rainfall, more water will seep into the ground ${ }^{[16]}$.

\subsubsection{Groundwater}

As can be seen in the subsystem of Groundwater, the increase in water consumption without adequate water supply will widen the gap between supply and demand. An increased gap requires a higher rate of groundwater extraction, which then decreases the groundwater level. But in the meantime, the groundwater can be recharged through percolation process ${ }^{[15]}$.

\subsection{System Dynamics Model}

The system dynamics or simulation model in Figure 5 is developed upon the conceptual system model shown in Figure 4. The model identifies stocks (level variables), flows (rates variables), and parameters and auxiliary variables influencing the flows in Figure 4 and quantifies the interactions within and across subsystems ${ }^{[37][56]}$. Furthermore, with the help of the Vensim 


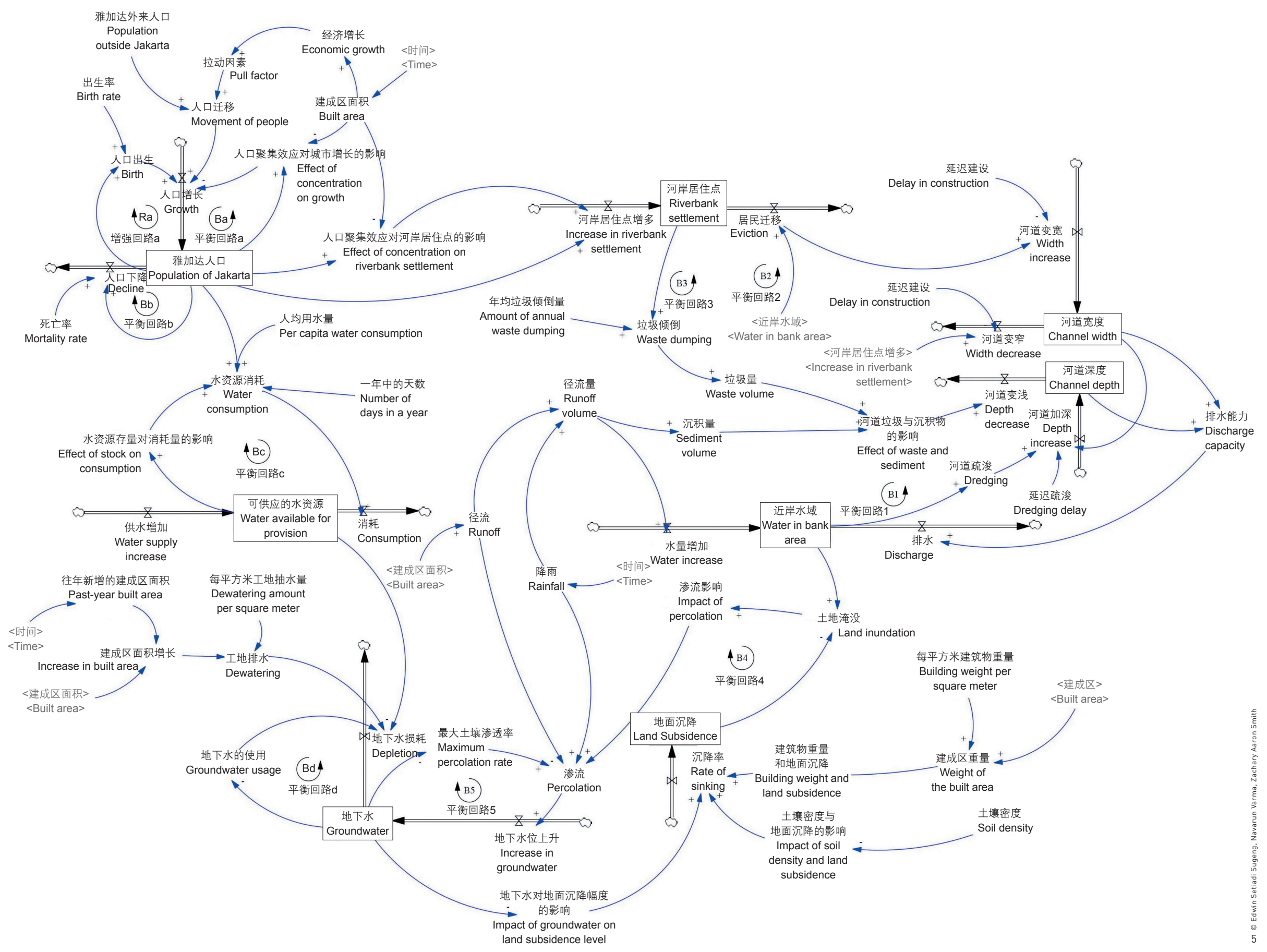

模型对1965 2050年的地面沉降、人口数量和土地淹没深度三个存量的 变化情况进行了基准数据对比与情景模拟。为确保模拟结果与实际问 题情景具有较高的拟合度, 本研究在情景模拟前首先进行了行为验证 ( 即检验模拟结果与有效历史数据是否吻合)。 software, the model is used to simulate the behavior of the three stocks - land subsidence, population, and land inundation depth from 1965 to 2050 for baseline and different scenarios. In order to validate the simulation results with the real-world situations, behavioral validation (a comparison of the simulation graph with available historical data) was firstly conducted before the scenario exercise.
5. 基于雅加达洪涝问题的 系统动力学模型

5. System dynamics model for flooding in Jakarta 


\section{2 .1 行为验证}

行为验证的目的是评估一个模型再现系统行为的能力 ${ }^{[37]}$ 。下文将 对系统中三个存量变量（即地面沉降、人口数量和土地淹没深度）的 模拟结果与图 2 及图 3 所示的实际数据进行对比验证。

从图6中可以看出，模拟的地面沉降幅度随时间推移不断增加，与 实际变化趋势相符。

如图7的模拟数据所示，1980 2020年间，雅加达人口迅速增长; 2020 年后, 人口增速减缓；2040年以后人口数量将趋于稳定。该模拟 变化趋势与实际数据几乎一致。

由图8中的模拟数据可知, 自 1965 年起, 土地淹没深度增长迅速, 并于1995年左右达到峰值。1995年以后, 土地淹没深度急剧下降, 在 2010年左右达到低谷。这一变化趋势与实际变化情况一致。此外, 模 拟结果还显示, 2010年以后, 土地淹没深度将持续增加, 并在2030年 左右达到新的峰值。以上结果表明, 如果继续实施 “河流正常化” 政 策, 雅加达抵御洪涝的能力将难以提高。因此, 必须积极探索其他可 行的防洪方案。

\subsection{2 情景模拟}

为提高雅加达的灾害防御能力及对未来不确定性的应对能力, 本 研究利用上述模型, 借鉴系统动力学中的敏感性分析, 进行了情景模 拟 ${ }^{[37}[157]$ 。图9呈现了降雨量预测、出生率、每平方米建筑物重量、建成 区面积、疏浚延迟及居民迁移延迟 6 个变量对土地淹没深度的影响。选

\subsubsection{Behavior Validation}

Behavior validation aims to assess the ability of a model in reproducing the behavior of a system ${ }^{[37]}$. In the following section, the simulation results of stock variables of the system, namely Land Subsidence, Population, and Land Inundation Depth, are compared to the actual data and shown in Figures 2 and 3.

As can be seen in Figure 6, the simulated land subsidence tends to increase over the time horizon, which matches the actual data.

In Figure 7, the simulated population of Jakarta increases rapidly from 1980 to 2020 . However, it seems to have a slower growth after 2020 and enters a plateau after 2040. The trend nearly replicates the actual data.

Figure 8 shows that the simulated land inundation depth increases rapidly from 1965 and reaches a peak at around 1995. After 1995, the depth decreases sharply, reaching a trough at around 2010. This trend is consistent with the actual data. The simulation further projects an increase in land inundation depth after 2010 and a new peak at around 2030, which illustrates the continuation of Jakarta's vulnerability to riverine flooding if the Normalisasi policy continues as usual. Thus, this projection may encourage exploration of alternative strategies to reduce the vulnerability.

\subsubsection{Scenario Exercise}

In order to explore leverage points for Jakarta in reducing vulnerability and managing resilience to future uncertainties, a scenario exercise was performed with the model. This exercise was adapted from the sensitivity analysis technique of system dynamics ${ }^{[37][59]}$. The magnitudes of variation in land inundation depth due to the value change of 6 variables, including rainfall projection, birth rate, building weight per square meter, built
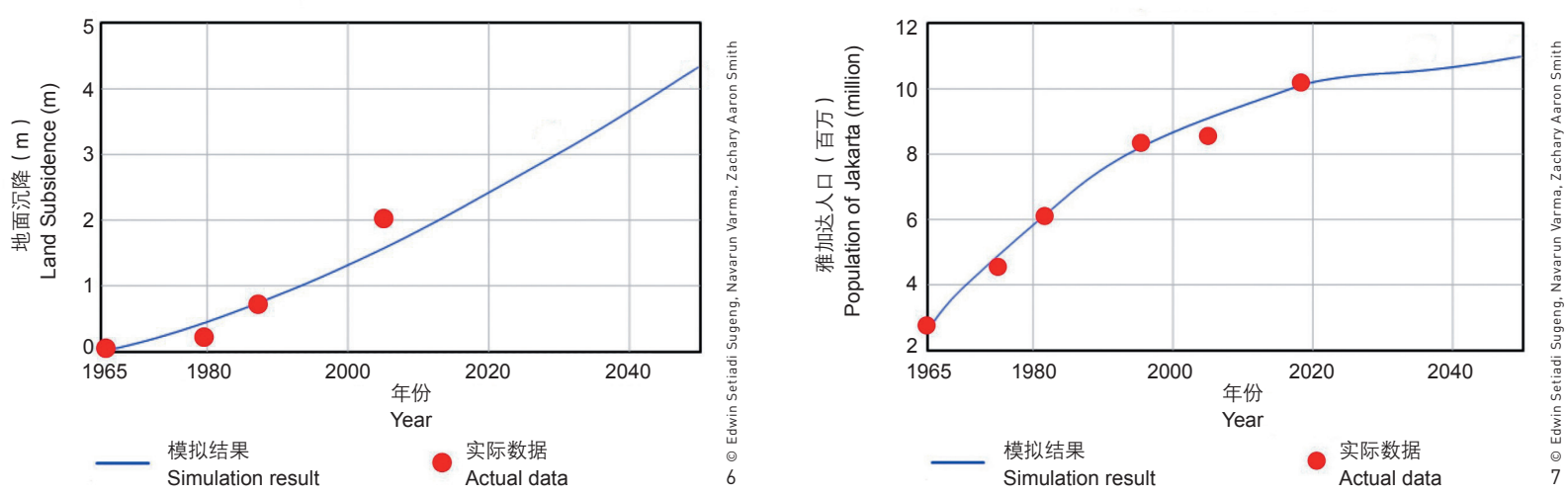

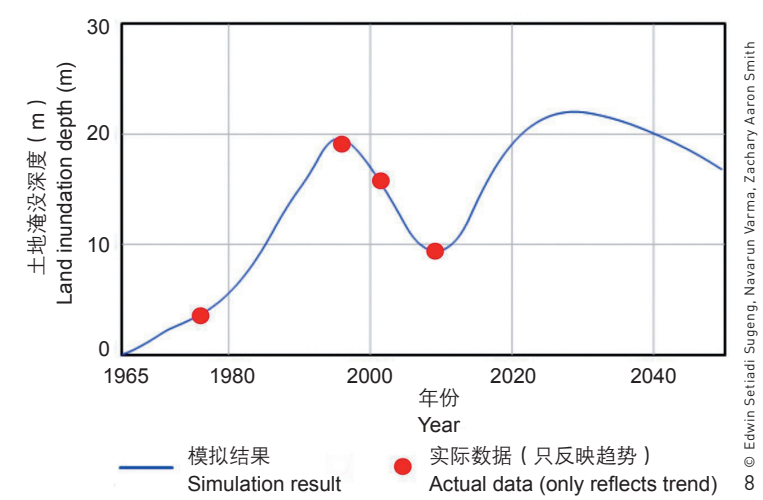



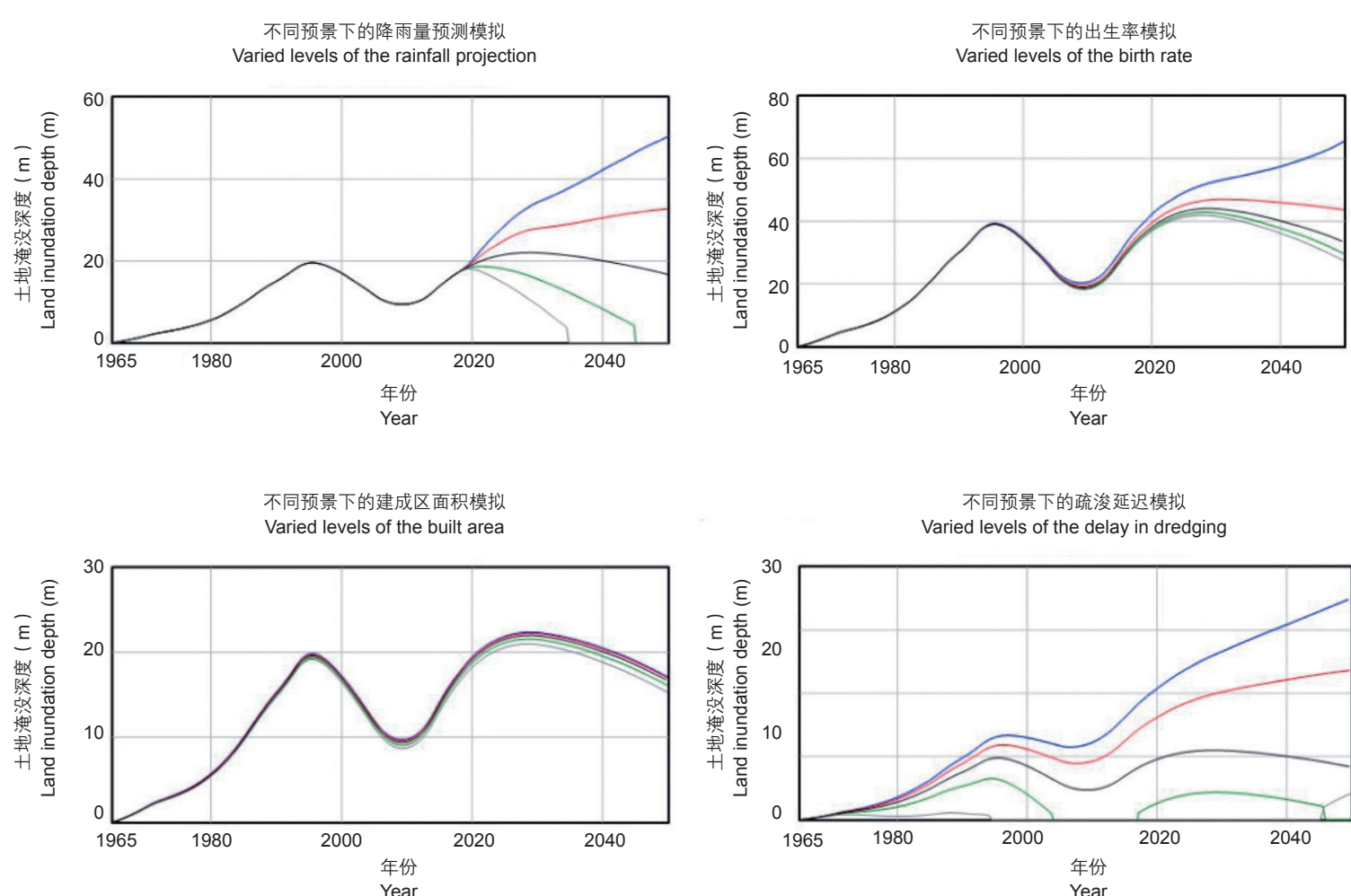

Year
不同预景下的每平方米建筑物重量模拟

Varied levels of the building weight per square meter

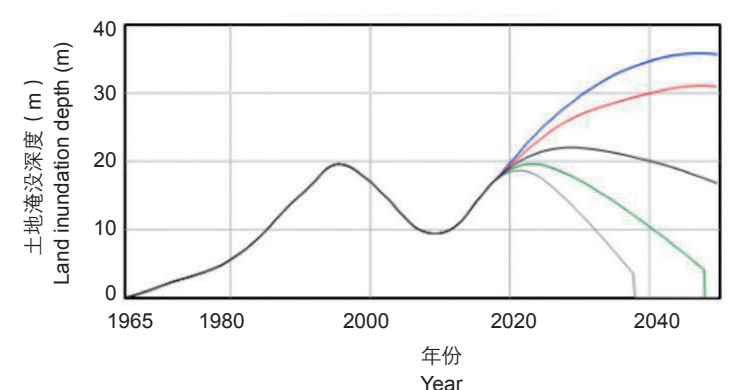

不同预景下的居民迁移模批 Varied levels of the delay in eviction

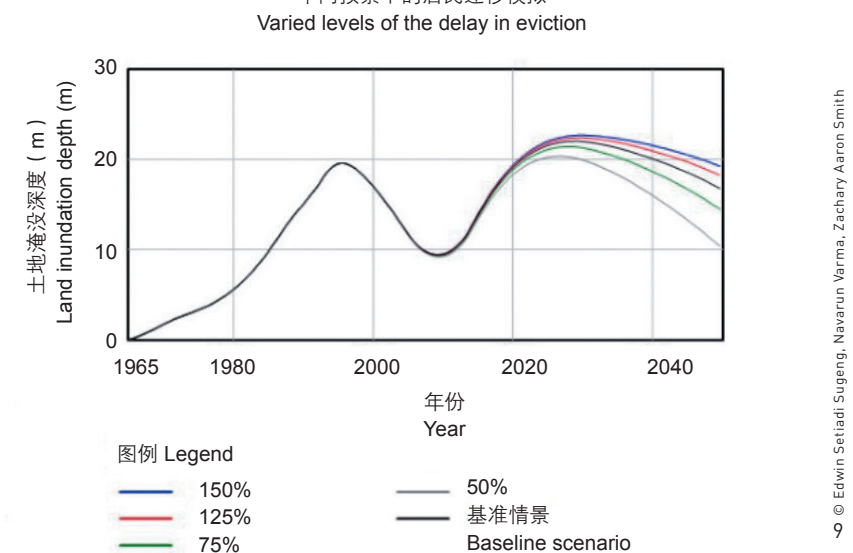

择以上 6 个变量的主要原因包括如下 4 点:

1 ) 降雨是雅加达洪涝频发的重要原因。在全球气候变化的影响之 下, 印度尼西亚未来的降雨模式将发生变化。因此, 有必要探究降雨 对土地淹没深度的影响。

2 ) 根据概念系统模型, 人口数量 (或出生率) 与建成区面积成正 比, 因此对土地淹没深度具有一定影响。

3 ) 情景模拟中包含每平方米建筑物重量和建成区面积这两个与城 市化进程相关的变量。由概念系统模型可知, 随着雅加达人口数量的 增长, 建成区面积也将不断扩大。但当建成区面积达到极值时, 人们 就不得不纵向扩张城市, 建筑物将越建越高, 每平方米建筑物重量也 就越大。因此, 这两个变量可体现城市化对土地淹没深度的影响。

4 ）疏浚措施和居民迁移措施可以反映 “河流正常化” 政策的实施 情况。通过在情景模拟中分析这两个变量, 能够了解政策成效的细微 差别。

各变量的影响程度如表2所示: 截至2050年, 如果该变量对土地淹 没深度的影响平均幅度不足 $50 \%$, 则视为 “低度影响” ; 如果该变量 的影响平均幅度在 50 100\%（含50\%与 $100 \%$ ) 之间, 则视为 “中度影 响” ; 如果该变量的影响平均幅度超过 $100 \%$, 则视为 “高度影响”。 area, delay in dredging, and delay in eviction, are illustrated in Figure 9. The 6 variables were chosen based on the following 4 reasons:

1) Rainfall is a main cause to Jakarta's vulnerability to flooding and there are future projections of rainfall pattern change in Indonesia as an impact of global climate change. Hence, the rainfall projection was selected to examine the impact on land inundation depth.

2) From the conceptual system model, the population, or birth rate, is directly proportional to the amount of built area and therefore will influence the land inundation depth.

3) Building weight per square meter and built area are proxy variables concerning urbanization for this scenario exercise. From the conceptual system model, the built area will increase with a growth of the population of Jakarta. However, when the built area reaches a threshold, the building weight per square meter will be increased because taller buildings will be constructed to compensate the finite space. Hence, these two variables were chosen to understand the impact of urbanization on land inundation depth. 


\begin{tabular}{|c|c|c|c|}
\hline \multirow{2}{*}{$\begin{array}{c}\text { 变量 } \\
\text { Variable }\end{array}$} & \multicolumn{3}{|c|}{$\begin{array}{c}\text { 影响程度 } \\
\text { Impact degree }\end{array}$} \\
\hline & $\begin{array}{l}\text { 低 } \\
\text { Low }\end{array}$ & $\begin{array}{c}\text { 中 } \\
\text { Medium }\end{array}$ & $\begin{array}{c}\text { 高 } \\
\text { High }\end{array}$ \\
\hline $\begin{array}{l}\text { 降雨量预测 } \\
\text { Rainfall projections }\end{array}$ & & & V \\
\hline $\begin{array}{l}\text { 出生率 } \\
\text { Birth rate }\end{array}$ & $v$ & & \\
\hline $\begin{array}{l}\text { 每平方米建筑物重量 } \\
\text { Building weight per square meter }\end{array}$ & & $V$ & \\
\hline $\begin{array}{l}\text { 建成区面积 } \\
\text { Built area }\end{array}$ & & $V$ & \\
\hline $\begin{array}{l}\text { 疏浚延迟 } \\
\text { Delay in dredging }\end{array}$ & & & $V$ \\
\hline $\begin{array}{l}\text { 居民迁移延迟 } \\
\text { Delay in eviction }\end{array}$ & $V$ & & \\
\hline
\end{tabular}

根据表 2 可知，未来降雨量的变化及资金匮乏导致的疏浚延迟 ${ }^{[32}$ 将 对土地淹没深度产生较大影响。此外, 随着城市化进程的推进, 建成 区面积的不断增加将对地面下沉深度产生中度影响。相较而言, 人口 出生率与居民迁移延迟对土地淹没深度的影响较小。上述分析结果表 明，尽管实施了 “河流正常化” 政策，城市的防洪及抵御未来风险的 能力并未得到显著提高，还需探索更有力的政策杜杆。

\section{5 政策成效检验一一未来的机遇与挑战}

基于表 2 中对土地淹没深度具有中度或高度影响的变量, 研究运用 系统动力学模型对两类策略进行了进一步检验, 继而对比并讨论其在 雅加达洪涝治理背景下实施时所面临的机遇与挑战。

\section{1 提升疏浚成效}

提升疏浚成效是以 “河流正常化” 政策为基础的更新策略，而非 一项全新的政策。作为 “河流正常化” 政策的一部分，疏浚工作的开 展完全取决于财政拨款情况 ${ }^{[32]}$ 。因此, 新策略应保障拨款, 提高疏浚效 率和成果, 以维持疏浚工作的持续开展。图10展示了系统动力学模型 下该策略的模拟结果：截至2050年，提升疏浚成效策略的实施将消除 洪水危机（最高洪水位降至 $0 \mathrm{~m} ） 。$

\section{2 综合水景政策}

水景概念常用于分析各种社会环境下水体的形成过程，以及水体 对于社会环境的影响，也涵盖人一水系统中的包容性维度。对于印度 尼西亚这样的发展中国家而言, 包容性非常重要——如果一味追求基
4) Dredging and eviction are proxy variables in connection with the Normalisasi policy. The changes in these two variables for the scenario exercise were used to explore nuances of effectiveness of the initiative.

The general impacts of these variables are summarized in Table 2. Here a low impact degree means a change of the land inundation depth by an average of under $50 \%$ by 2050 ; a medium impact degree means a change by an average of $50 \% \sim 100 \%$ (both inclusive) by 2050 ; and a high impact degree indicates a change by an average of above $100 \%$ by 2050 .

Based on Table 2, the change in rainfall projection and the delay in dredging due to a lack of funding ${ }^{[32]}$ highly impact the land inundation depth. Furthermore, the increasing concrete spaces (built area) due to growing urbanization results in a moderate impact. Comparatively, the impacts of the birth rate and delay in eviction on the land inundation depth are low. This analysis not only illustrates the continuation of the city's vulnerability and future risks for flooding in spite of Normalisasi, but also indicates policy levers to be explored further.

\section{Policy Testing - Opportunities and Challenges for Ways Forward}

Based on the variables which moderately and highly impact the land inundation depth in Table 2, two categories of strategies are further tested in the system dynamics model. Both categories will then be compared and discussed regarding opportunities and challenges for their implementation in Jakarta's flood governance context.

\subsection{Increasing Dredging Efficiency}

This category of increasing dredging efficiency is built upon the Normalisasi policy and hence is more of an updated strategy than a new policy. The implementation of dredging, one of the components of Normalisasi, depends heavily on the amount of funds allocated ${ }^{[32]}$. Hence, the new strategy is to maintain a continuous dredging process with a higher speed and yield with the allocation of more funds. Figure 10 illustrates the simulation result of this strategy in the model: it predicts that the implementation of the strategy can reduce the flood level by $100 \%$ by 2050 .

\subsection{An Integrated Waterscape Policy}

Waterscape is a concept used to analyze how the society shapes water in any context and how the society is in turn shaped by water. It also looks at the inclusivity dimension within any human-water system. This dimension is important in developing 

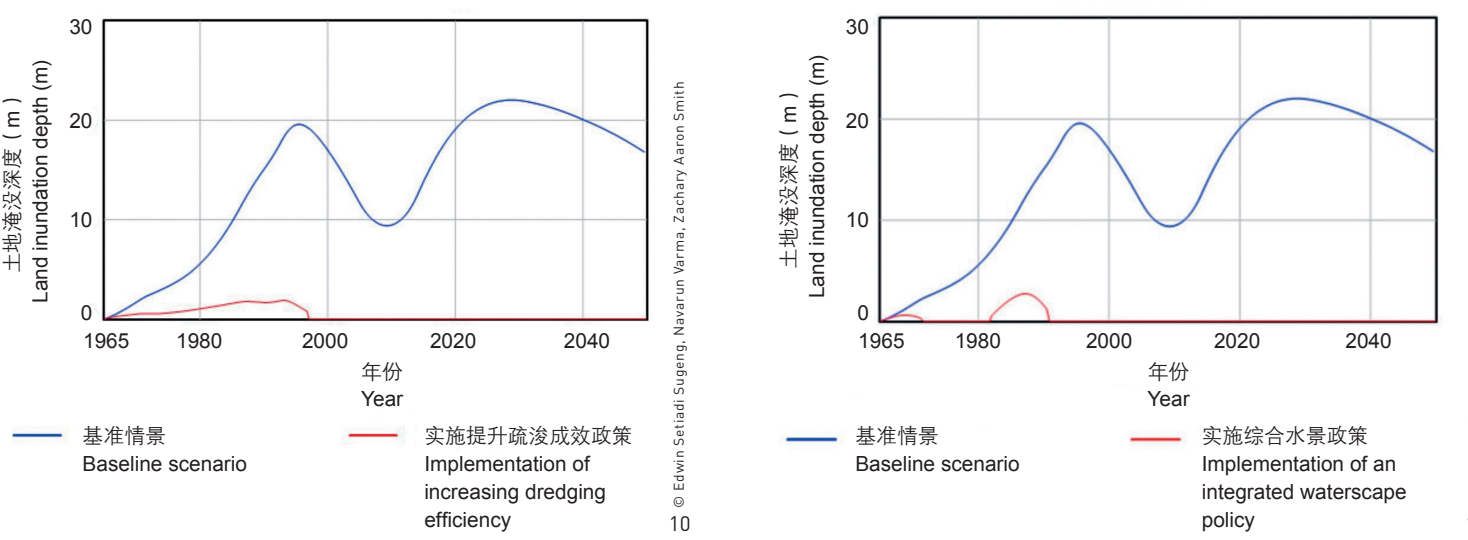

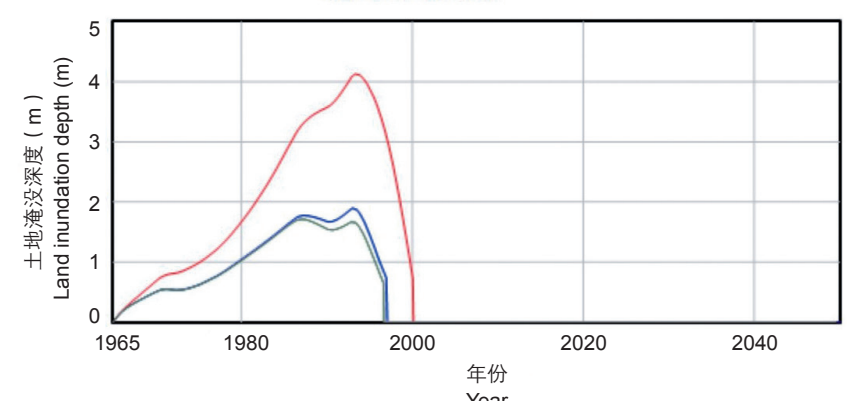

现有政策实施成效 Existing policy implementation

政策成效检验（预景为河道容量减少 $15 \%$ 、建成区面积减少 $40 \%$, 以及建筑物 重量减少 $60 \%$ )

Policy testing under the scenario of channel capacity reduced by $15 \%$, built area decreased by $40 \%$, and building weight decreased by $60 \%$

政策实施成效 (预景为降雨量增加 $50 \%$ )

Policy implementation with the scenario of rainfall increased by $50 \%$ Policy implementation with the scenario

Policy implementation with the scenario of rainfall decreased by $50 \%$
础设施的发展速度，而不考虑河岸居民等社会边缘群体的利益，那么 公共政策的制定和实施都极有可能以失败告终 ${ }^{[58]}$ 。因此，综合水景政 策需全面纳人新的建筑规范，在基础设施开发过程中制定绿地保护条 例, 并通过修建水库提高气候变化应对能力。运用系统动力学模型检 验综合水景政策后得出如下模拟结果（图11）：预计截至2050年，综 合水景政策的实施也将消除洪水危机（最高洪水位降至 $0 m$ ）。

此外，综合水景政策不仅可以提高城市的防洪能力，还能够帮助 其从容应对未来气候变化影响下的不同降雨强度。由图12中的绿线和 灰线可知, 2020 年以后, 即使是在降雨量增加或减少 $50 \%$ 的预景下 ${ }^{[34]}$, 洪涝程度也不会发生变化。此外, 建设小型水库、提高绿地面积（这 也是维持雅加达洪水位的必要措施）也能够提高综合水景政策的成本 效益。

\section{3 对比与分析}

为了更全面地探究以上两类政策在实施过程中的机遇与挑战, 研究 对二者进行了成本一效益对比, 结果如表3所示。短期来看, “河流正常 化” 政策之下的疏浚成效提升策略成本效益较高。但需要注意的是, 用 于疏浚的财政拨款会随着特定年份的洪涝程度而有所增减。而综合水景 政策的效益则长久而全面，也具备一定应对未来气候变化的能力。

另一方面，提升疏浚成效的策略仅关注当前的河道情况，而忽略 了城镇化进程 (例如随着人口数量的增长和经济的发展, 建成区面积 会相应增加) 、河道一洪泛平原动力学 (例如随着人口数量的增长和 地面沉降的加剧, 地下水会枯竭) 及未来气候变化 (例如降水减少) 等重要因素的影响。尽管这一策略可能会因缺乏远见而被诟病 ${ }^{[00]}$, 但由 于其是 “河流正常化” 政策既有施行框架之下的提升策略，因而较易 实现 ${ }^{[2] 139]}$ 。 countries like Indonesia as the public policy design and implementation will be unsuccessful if marginalized sections of the society, such as the settlers in riverbank areas, are left behind in a rush for infrastructure development ${ }^{[58]}$. Hence, the integrated waterscape policy can be regarded as a combination of a new building code, regulations for maintaining green area during infrastructure development, as well as the construction of reservoirs to ensure climate resilience. Upon testing of the policy in the model, the following simulation result is attained: the implementation of the policy may also reduce the flood level by $100 \%$ by 2050 (Fig. 11).

Moreover, the implementation of this policy not only reduces the vulnerability to flooding, but also builds Jakarta's resilience to different levels of rainfall as indicated for future climate projections ${ }^{[34]}$. As shown by the green and grey lines in Figure 12, the flood level after 2020 will not change, even when the rainfall is increased and decreased by $50 \%$, respectively ${ }^{[34]}$. Furthermore, the implementation of the policy could be made more cost-efficient by creating smaller-size reservoirs and more green areas that Jakarta must have to maintain the flood level.

\subsection{Comparison and Discussion}

In order to give a bigger picture of the opportunities and challenges for policy implementation, a cost-benefit comparison between the two policy categories was conducted (Table 3). The strategy of increasing dredging efficiency within Normalisasi seems to be cost-efficient in the short term. But it is important to note that the budget allocated for this strategy may fluctuate, depending on the level of flood of a specific year. As with
(4) 政府每年预留约9 350万美 元用于疏浚作业。拨款数 额会根据当年的疏浚情况 和居民迁移要求, 以及 提升的疏浚效率有所波 动 $[27]$ 。

根据模拟结果, 雅加达的 水库面积需达约 $47.5 \mathrm{~km}^{2}$ 。

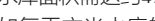
如每平方米水库的建设费 用为 2 美元, 水库建设成本 约9 500万美元 ${ }^{[5]}$ 。

6) 边界组织指能够促进不同 研究领域之间以及研究与 公共政策之间的协作与信 息交流的组织。

(4) The government sets aside approximately USD 93.5 million each year for dredging. However, an increasing dredging efficacy may require funds more or less than the amount above, dependin on the dredging and eviction requirements of that year ${ }^{[27]}$.

(5) Based on the simulation Jakarta requires approximately 47.5 square kilometers of reservoir. The construction of one square meter of reservoir costs USD 2. When multiplied, USD 95 million is required ${ }^{[59]}$.

(6) Boundary organizations are organizations that facilitate collaboration and information flow between diverse research disciplines and between the reserch and public policy community. 
12. 不同预景下雅加达防 洪能力与政策实施成 本效益

10. Simulation result of policy testing: increasings dredging efficacy

11. Simulation result of policy testing: an integrated waterscap policy

12. Resilience of Jakarta and the costefficiency of policy implementation under different scenarios

优化水景政策对比

Table 3: Comparison of the policy categories between increasing dredging efficiency and the integrated waterscape policy

\begin{tabular}{|c|c|c|}
\hline $\begin{array}{c}\text { 对比标准 } \\
\text { Criteria for comparison }\end{array}$ & $\begin{array}{c}\text { 提升疏浚成效 } \\
\text { Increasing dredging efficiency }\end{array}$ & $\begin{array}{c}\text { 优化水景 } \\
\text { An integrated waterscape policy }\end{array}$ \\
\hline $\begin{array}{c}\text { 对土地淹没深度的影响 } \\
\text { Impact on land inundation depth }\end{array}$ & $\begin{array}{l}\text { 显著 } \\
\text { Significant }\end{array}$ & $\begin{array}{l}\text { 显著 } \\
\text { Significant }\end{array}$ \\
\hline $\begin{array}{l}\text { 成本 } \\
\text { Cost }\end{array}$ & $\begin{array}{l}\text { 每年需约9 } 350 \text { 万美元的预算 } \\
\text { May require an annual budget up to USD } \\
93.5 \text { million }\end{array}$ & $\begin{array}{l}\text { 需约9 500万美元的一次性预算 } \\
\text { May require one-time budgetary allocation } \\
\text { up to USD } 95 \text { million }^{5}\end{array}$ \\
\hline $\begin{array}{c}\text { 效益 } \\
\text { Benefit }\end{array}$ & $\begin{array}{l}\text { 能够减少土地淹没 } \\
\text { Can reduce land inundation }\end{array}$ & $\begin{array}{l}\text { 能够减少土地淹没、提高干旱时期的供水能 } \\
\text { ， 改善城市观观 } \\
\text { Can reduce land inundation, increase water } \\
\text { supply during low rainfall, and improve } \\
\text { urban landscape }\end{array}$ \\
\hline
\end{tabular}

青 4: 两种政策实施过程中的政府机构管辖范围设想

Table 4: Institutions and levels of jurisdiction envisaged for implementation of the two policy categories

\begin{tabular}{|c|c|c|}
\hline $\begin{array}{c}\text { 参与机构 } \\
\text { Institutions involved }\end{array}$ & $\begin{array}{c}\text { 提升疏浚成效 } \\
\text { Increasing dredging efficiency }\end{array}$ & $\begin{array}{c}\text { 综合水景政策 } \\
\text { An integrated waterscape policy }\end{array}$ \\
\hline $\begin{array}{l}\text { 省级政府部门 } \\
\text { Provincial government institutions }\end{array}$ & $\begin{array}{l}\text { 雅加达首都特区政府 } \\
\text { Jakarta Special Capital Region Provincial } \\
\text { Government }\end{array}$ & $\begin{array}{l}\text { 雅加达首都特区政府 } \\
\text { Jakarta Special Capital Region Provincial } \\
\text { Government } \\
\text { 雅加达政府水资源局 } \\
\text { Department of Water Resources of the } \\
\text { Government of Jakarta }\end{array}$ \\
\hline $\begin{array}{c}\text { 国家政府部门 } \\
\text { National government institutions }\end{array}$ & $\begin{array}{l}\text { 吉利翁河与西萨丹河管理中心 } \\
\text { Center for the Ciliwung River and Cisadane River } \\
\text { 印度尼西亚公共事业与住房部 } \\
\text { Ministry of Public Works and Housing }\end{array}$ & $\begin{array}{l}\text { 印度尼西亚标准委员会 } \\
\text { National Standards Board } \\
\text { 印度尼西亚公共事业与住房部 } \\
\text { Ministry of Public Works and Housing }\end{array}$ \\
\hline
\end{tabular}

the integrated waterscape policy, the benefits associated are long terms and multi-sectoral and it also targets capacities for managing resilience for future shocks.

On the other hand, the strategy of increasing dredging efficiency focuses only on river channels at the current time, ignoring mainstreaming issues of urbanization (e.g. increasing built area with population and economic growth), river channel-flood plain dynamics (e.g. groundwater depletion with increasing population and land subsidence), and future climate change impacts (e.g. decreasing rainfall). But the revision strategy may be less difficult as it is within the context of the established actions of Normalisasi ${ }^{[2][39]}$, though may be argued to be myopic ${ }^{[60]}$.

Table 4 provides the extent of institutional involvement that can be envisaged for the implementation of the two policy categories. The strategy of increasing dredging efficiency may seem to be less complex as it may involve fewer government institutions, compared with the integrated waterscape policy. But a lack of participation of a greater number of institutions in policy planning and implementation may just reinforce the already existing policy myopia. On the other hand, the integrated waterscape policy may face challenges to fit in existing institutional arrangements and governance protocols and will require innovations in governance ${ }^{[2]}$. In this regard, this policy might need to bridge institutions at different jurisdictional levels for policy planning and academic and civil organizations for technical advisory, as well as awareness raising by monitoring and evaluation. To institutionalize such a polycentric governance approach, a boundary organization ${ }^{6}$ with stakeholders from the government, academia, and civil society should be initiated in Jakarta ${ }^{[6]]}$.

\section{Conclusion}

This study developed a system dynamics model to illustrate the interplay of social and hydro-geomorphological factors leading to Jakarta's vulnerability to current flooding and evaluate current policy response, as well as two other categories of policy against this vulnerability and future shocks in the context of Jakarta.

The model simulation illustrated the continuation of vulnerability to urban flooding in Jakarta even with the current policy of Normalisasi, though current data demonstrates a respite. The policy reduces the systemic issue of flooding only to the river channel, discounting elements of urbanization, groundwater depletion, land subsidence, and mainstreaming climate risks. Policy testing and further comparison revealed 
程、地下水枯竭、地面沉降及气候变化等因素。接下来的政策成效检 验与对比揭示了提升疏浚成效与综合水景提升两项政策带来的机遇和 挑战。短期而言, 前者成本效益较高, 跨部门合作难度较小; 后者由 于更全面地考虑了造成雅加达洪涝原因的各个因素及其未来可能面临 的气候变化风险, 因而能够提高城市的长期防洪能力, 但其施行需依 靠多中心治理制度保障机制, 同时建立边界组织, 鼓励不同治理主体 的参与。

与其他基于建模的研究一样, 本研究也存在不足之处。首先, 系 统动力学模型中缺少建成区面积与人口增长之间的关系计算公式。由 于缺乏雅加达建成区面积与人口增长之间的关系数据，图5所示的模型 将二者视为相互独立的变量。未来的研究也需关注影响建成区面积的 其他经济和政策因素。其次，本次建模分析未考虑海平面变化与土地 淹没深度之间的关系。由于雅加达属沿海城市, 未来的研究应将海平 面上升因素及相关预测结果纳人考虑范畴 ${ }^{[2]}$ 。

尽管存在一定的缺陷, 但该系统动力学模型依旧为印度尼西亚及 其他亚洲国家的城市空间政策与治理提供了思路与建议。这种建模方 式应当成为亚洲城市相关政策制定与评估的重要一环，或为公共政策 决策过程中各利益相关方之间的磋商提供依据。本研究同时建议边界 组织应对模型的结果输出与数据分析进行把控。LAF the opportunities and challenges for the two categories of policy — increasing dredging efficiency and an integrated waterscape policy. Although the former seems to be cost-efficient in short term and less complex for institutional interplay, the latter will help strengthen long-term resilience as it more holistically considers the factors of Jakarta's flooding issue and its future climate risks. However, implementation of such an integrated waterscape policy will require the institutionalization of polycentric governance and a boundary organization to increase the participation of diverse actors across governance levels.

Like in any other modeling-based study, there are limitations of the study. First, there is an absence of a formulation between built area and population in the system dynamics model. In the model shown in Figure 5, the population and built area of Jakarta are assumed to be independent of each other. The assumption was taken due to the unavailability of data of built area in relation to population growth. Further work is also needed in this aspect by exploring other economic and policy factors that may influence built area. Second, the linkage between sea level and land inundation depth is not considered in this modeling analysis, which requires to be further studied as Jakarta is a coastal city and there are projections of sea level rise ${ }^{[62]}$.

This system dynamics model, even with its limitations, raises interesting propositions for policy and governance in urban spaces not only for Indonesia but also for the rest of Asia. It is important that such a modeling exercise is taken as an integral part of the design and evaluation of policies in Asian urban contexts. Furthermore, it can also be accessible to stakeholder consultations for public policy. Boundary organizations, as suggested here, can take ownership of modeling output and process. LAF
[1] Intergovernmental Panel on Climate Change. (2012). Managing the Risks of Extreme Events and Disasters to Advance Climate Change Adaptation. New York: Cambridge University Press.

[2] Johannessen, A., Swartling, A. G., Wamsler, C., Andersson, K., Arran, J. T., Vivas, D. I., \& Stenstrom, T. A. (2018). Transforming urban water governance through social (tripleloop) learning. Environmental Policy and Governance, 29(2), 144-154. doi:10.1002/eet. 1843

[3] Koh, T. (2016, July 9). Solving Asia's water woes by 2030 Retrieved from https://www.straitstimes.com/opinion/solving- asias-water-woes-by-2030

[4] Da Silva, J., Kernaghan, S., \& Luque, A. (2012). A system approach to meeting the challenges of urban climate change. International Journal of Urban Sustainable Development, 4(2). 125-145. https://doi.org/10.1080/19463138.2012.718279

[5] Narain, V., \& Prakash, A. (2016). Water security in peri-urban South Asia adapting to climate change and urbanization. New Delhi: Oxford University Press.

[6] World Bank. (2016). World Development Indicators. Washington D.C.: World Bank Group. Retrieved from https:// openknowledge.worldbank.org/handle/10986/2396
[7] Moreno, E. L. (2017, September 7). Concepts, Definitions and Data Sources for the Study of Urbanization: The 2030 Agenda for Sustainable Development. Retrieved from http:// www.un.org/en/development/desa/population/events/pdf/ expert/27/papers/II/paper-Moreno-final.pdf

[8] Badan Pusat Statistik. (2010). Peraturan Kepala Badan Pusa Statistik Nomor 37 tahun 2010 tentang Klasifikasi Perkotaan dan Pedesaan di Indonesia [Regulation of the Head of the Central Bureau of Statistics Number 37 of 2010 concerning Classification of Urban and Rural Areas in Indonesia]. Jakarta: Badan Pusat Statistik. Retrieved from https://sirusa. 
bps.go.id/webadmin/doc/MFD_2010_Buku_1.pdf

9] WIB. (2018, January 25). Berapa Kepadatan Penduduk di DKI Jakarta? [What is the Population Density in DK Jakarta?]. Retrieved from https://databoks.katadata.co.id/ datapublish/2018/01/25/berapa-kepadatan-penduduk-di-dkijakarta

[10] Jakarta Open Data. (2018, May 17). Data Penduduk Berdasarkan Pekerjaan Di DKI Jakarta [Employment-Based Population Data in DKI Jakarta]. Retrieved from http://data. jakarta.go.id/dataset/datapendudukdkijakartaberdasarkanp kerjaan

[11] Ministry of Internal Affairs of the Republic of Indonesia. (2014). Pembentukan Daerah-Daerah Otonom di Inodnesia sampai dengan Tahun 2014 [Establishment of autonomous regions in Indonesia up to 2014]

[12] Viaz, N. (2017, November 6). 15 Kota Maju dan Kota Metropolitan di Indonesia [15 Advanced Cities and Metropolitan Cities in Indonesia]. Retrieved from http:// biasaaja.com/kota-metropolitan-di-indonesia/

[13] Human Cities Coalition. (2017, January 25). Jakarta Urban Challenges Overview. Retrieved from https://www. humancities.co/2017/01/jakarta-urban-challenges-overview/

[14] WIB. (2018, January 24). Berapa Jumlah Penduduk Jakarta? [What is the population of Jakarta?]. Retrieved from https:// databoks.katadata.co.id/datapublish/2018/01/24/berapajumlah-penduduk-jakarta

[15] Abidin, H. Z., Andreas, H., Gumilar, I., Fukuda, Y., Pohan, Y. E. \& Deguchi, T. (2011). Land subsidence of Jakarta (Indonesia) and its relation with urban development. Natural Hazards, (59) 1753-1771. https://doi.org/10.1007/s11069-011-9866-9

[16] Deltares. (2015). Sinking cities: An integrated approach towards solutions. Retrieved from https://www.deltares.nl/ app/uploads/2015/09/Sinking-cities.pdf

[17] Moe, I. R., Kure, S., Januriyadi, N. F., Farid, M., Udo, K., Kazama, S., \& Koshimura, S. (2016). Effect of Land Subsidence on Jakarta, Indonesia. Journal of Japan Society of Civil Engineers, 72(5), I_283-I_289. doi:10.2208/jscejer.72. । 283

[18] Kimmelman, M. (2017, December 21). Jakarta is Sinking so Fast, it could end up underwater. Retrieved from https://www nytimes.com/interactive/2017/12/21/world/asia/jakartasinking-climate.html

[19] Lin, M. M., \& Rifky, H. (2018, August 13). Jakarta, the fastestsinking city in the world. Retrieved from https://www.bbc com/news/world-asia-44636934

[20] Richards, E. (2018, November). 4 Sinking Asian cities that could be drowned by climate change. Retrieved from https:// asiancorrespondent.com/2018/11/4-sinking-asian-citiesthat-could-be-drowned-by-climate-change/

[21] Galloway, D., Jones, D. J., \& Ingebritsen, S. E. (2013). Land Subsidence in the United States. Retrieved from https://pubs. usgs.gov/circ/circ1182/pdf/03intro.pdf

[22] Kooi, H., \& Yuherda, A. T. (2018). Updated subsidence scenarios Jakarta. Retrieved from https://www.deltares.nl/ app/uploads/2018/09/11202275-008-BGS-0004-r-Updatedsubsidence-scenarios-Jakarta-DEF.pdf

[23] Walker, B., Holling, C. S., Carpenter, S. R., \& Kinzig, A. $(2004)$ Resilience, Adaptability and Transformability in Social Ecological Systems. Ecology and Society, 9(2), 5. Retrieved from http://www.ecologyandsociety.org/vol9/iss2/art5/

[24] Mao, F., Clark, J., Karpouzoglou, T., Dewulf, A., Buytaert, W., \& Hannah, D. (2017). HESS Opinions: A conceptual framework for assessing socio-hydrological resilience under change. Hydrology Earth Systems Science, (21), 3655-3670. doi:10.5194/hess-21-3655-2017

[25] Syatiri, A. S. (2017, February 21). Banjir Jakarta dari 1872 hingga 2015 [Jakarta floods from 1872 to 2015]. Retrieved from https://megapolitan.kompas.com/read/2017/02/21/11092351/ banjir.jakarta.dari.1872.hingga.2015

[26] Smith, Z. A. (2017). Hydro-Social Systems of Jakarta: A Critique of Flood Management Policy (Master's thesis, National University of Singapore, Singaporel. Retrieved from https://scholarbank.nus.edu.sg/handle/10635/142756

[27] Febriani, G. A. (2018, November 12). Mandeknya Normalisasi Kali Ciliwung [The stagnation of the Normalization of Ciliwung River]. Retrieved from https://x.detik.com/detail/
investigasi/20181112/Mandeknya-Normalisasi-KaliCiliwung/

[28] Lin, E., Shaad, K., \& Girot, C. (2016). Developing river rehabilitation scenarios by integrating landscape and hydrodynamic modeling for the Ciliwung River in Jakarta, Indonesia. Sustainable Cities and Society, (20), 180-198. doi:10.1016/j.scs.2015.09.011

[29] Kuwado, F. J. (2013, November 20). Atasi Banjir, Apa Bedanya Foke dengan Jokowi? [Overcome the Flood, What's the Difference between Foke and Jokowi?]. Retrieved from https://megapolitan.kompas.com/read/2013/11/20/0804066/ Atasi Baniir Apa Bedanya Foke dengan Jokowi ?page=2

01 Nugro, S. A. (2017, December 13). Angga Normalls Berhasil, Warga Kampung Pulo Masih Khawatir [Assumin Normalization Succeeds, Kampung Pulo Residents Still Worry]. Retrieved from https://megapolitan.kompas.com/ read/2017/12/13/13215901/anggap-normalisasi-berhasilwarga-kampung-pulo-masih-khawatir

[31] Febriani, G. A. (2018, November 14). Jeritan Ganti Rugi Warga Bantaran Ciliwung [Compensation Scream Citizens Bantaran Ciliwungl. Retrieved from https.//x detik.com/ detail/investigasi/20181113/Jeritan-Ganti-Rugi-WargaBantaran-Ciliwung/

[32] Wijaya, L. D. (2019, March 22). Normalisasi Sungai Ciliwun dan Pesanggrahan Mandek [Normalization of the Ciliwung River and Pangganggrahan Mandek]. Retrieved from https://metro.tempo.co/read/1188162/normalisasi-sungaiciliwung-dan-pesanggrahan-mandek

[33] Pratama, A. M. (2017, February 22). Faktor Penyebab Banjir Jakarta, Aktivitas Warga Ikut Berperan [Factors causing Jakarta floods and citizen activities involved]. Retrieved from https://megapolitan.kompas.com/ $\mathrm{read} / 2017 / 02 / 22 / 15564111 /$ faktor.penyebab.jakarta.banjir. ktivitas.warga.ikut.berperan

[34] Hausfather, Z. (2018, January 19). Explainer: What climate models tell us about future rainfall. Retrieved from https:// www.carbonbrief.org/explainer-what-climate-models-tellus-about-future-rainfal

[35] Renzi, A. (2018, February 3). Jakarta should not turn to mass evictions as part of city planning for economic success. Retrieved from https://www.independent.co.uk/life-style/ design/jakarta-indonesia-city-planning-mass-evictionseconomy-growth-success-a8186136.html

[36] Nailufar, N. N. (2018, September 13). Jakarta Masih Terancam Bencana Banjir [Jakarta Still Threatened by Flood Disasters]. Retrieved from https://megapolitan.kompas. com/read/2018/09/13/09413271/jakarta-masih-terancambencana-banjir

[37] Sterman, J. D. (2000). Business Dynamics: Systems Thinking and Modelling for a Complex World. Masachussetts: McGraw-Hill Education.

[38] Sendzimir, J., Reij, C. P., \& Magnuszewski, P. (2011). Rebuilding Resilience in the Sahel: Regreening in the Marad and Zinder Regions of Niger. Ecology and Society, 16(3), 1. http://dx.doi.org/10.5751/ES-04198-160301

[39] Varma, N., \& Mishra, A. (2017). Discourses, Narratives and Purposeful Action - Unraveling the Social-Ecological Complexity within the Brahmaputra Basin in India. Environmental Policy and Governance, 27(3), 207-228. Environmental Policy and Gover

[40] Smith, S. (2018, March 1). The world needs to build more than two billion new homes over the next 80 years. Retrieved from https://theconversation.com/the-world-needs-tobuild-more-than-two-billion-new-homes-over-the-next-80years-91794

[41] Denison, E. F. (1980). The Contribution of Capital to Economic Growth. The American Economic Review, 70(2), 220-224. Retrieved from www.jstor.org/stable/1815471

[42] Knoll, S. (2014, June 3). Economic growth and developing world cities: The benefits of urban clustering. Retrieved from https://journalistsresource.org/studies/environment/cities/ economic-growth-developing-world-cities-benefits-urbanclustering/

[43] Lewis, P. C. (n.d.). Physical Capital. Encyclopaedia Britannica. Retrieved from https://www.britannica.com/topic/physicalcapital
[44] National Infrastructure Commission. (n.d.). Economic Growth and Demand for Infrastructure Services. Retrieved from https//wum nic.org uk/wp-content/uploads/2906219NIC-Technical-Paper-Economic-Driver-v1_0AWEBACCESSIBLE.pdf

[45] Putri, W. D. (2016, February 29). Perkembangan Populas Penduduk Menjadi Tantangan Pasokan Air di Jakarta Challenges of Population Development on Water Supply in Jakarta]. Republika. Retrieved from https://republika.co.id/ berita/ekonomi/palyja/16/02/29/03ajy7359-perkembanganpopulasi-penduduk-menjadi-tantangan-pasokan-air-dijakarta

[46] Purnamasari, N. (2016, September 28). Alasan Ahok Percepat Penggusuran Bukit Duri: Normalisasi Sungai! [Normalisasi: Reasons to Accelerate Riverbank Settlement Eviction]. Detik. Retrieved from https://news.detik.com/ berita/d-3308451/alasan-ahok-percepat-penggusuranbukit-duri-normalisasi-sungai

[47] Texier, P. (2008). Floods in Jakarta: When the extreme reveals daily structural constraints and mismanagement. Disaster Prevention and Management, 17(3), 358-372. doi:10.1108/09653560810887284

[48] Putri, N. N. (2018, December 3). Antisipasi Banjir, Program Normalisasi Sungai di Jakarta Berlanjut [Anticipation of Flood, Normalisasi Program in Jakarta Continues]. detikNews. Retrieved from https://news.detik.com/berita/ d-4328335/antisipasi-banjir-program-normalisasi-sungaidi-jakarta-berlanjut

[49] Nelson, S. A. (2016, October 18). River Systems and Causes of Flooding. Retrieved from http://www.tulane. edu/ sanelson/Natural_Disasters/riversystems.htm

[50] Rhode Island Department of Environmental Management. (n.d.). Soil Erosion, Runoff, and Sedimentation. Retrieved from http://www.dem.ri.gov/programs/benviron/water/ permits/ripdes/stwater/pdfs/factsh1.pdf

[51] Zhang, G., Feng, G., Li, X., Xie, C., \& Pi, X. (2017). Flood Effect on Groundwater Recharge on a Typical Silt Loam Soil. Water, 9(7), 523-537. doi:10.3390/w9070523

[52] Proteinnson, P. (n.d.). The Hydrological Cycle. Retrieved from https://notendur.hi.is/thorstur/teaching/vatna/ HYDROCYCLE.PDF

[53] Fluence News Team. (2016, January 6). What is Percolation?. Retrieved from https://www.fluencecorp.com/ what-is-percolation/

[54] Wood, C. (2006, February). Soil Bulk Density Sampling. Retrieved from http://nora.nerc.ac.uk/id/eprint/503786/1/ CS2007_Bulk_Density_Scoping.pdf

[55] Horn, R., \& Lebert, M. (1994). Soil Compactability and Compressibility. Developments in Agricultural Engineering (111). 45-69. doi:10.1016/B978-0-444-88286-8.50011-8

[56] Ford, A. (1999). Modelling the Environment: An Introduction to System Dynamics Models of Environmental Systems. Washington, D.C.: Island Press.

[57] Breierova, L., \& Choudhari, M. (1996). An Introduction to Sensitivity Analysis. Massachussetts: Massachussetts Institute of Technology.

[58] Karpouzoglou, T., \& Vij, S. (2017). Waterscape: A perspective for understanding the contested geography of water. WIREs Water, 1-5. doi:10.1002/wat2.1210

[59] Himawan, A., \& Hapsari, D. K. (2017, January 31). Hingga 2019, Kementerian PUPR akan Bangun 65 Bendungan [Up to 2019, the PUPR Ministry Will Build 65 Dams]. SUARA. Retrieved from https://www.suara.com/ bisnis/2017/01/31/144743/hingga-2019-kementerian-puprakan-bangun-65-bendungan

[60] Nair, S., \& Howlett, M. (2017). Policy myopia as a source of policy failure: Adaptation and policy learning under deep uncertainty. Policy and Politics, 45(1), 103-118. doi:10.1332/ $030557316 \times 14788776017743$

[61] Carlisle, K., \& Gruby, R. L. (2017). Polycentric Systems of Governance: A Theoretical Model for the Commons. Policy Studies Journal, (0), 1-26. doi:10.1111/psj.12212

[62] Nunez, C. (2019, Feburary 19]. Sea level rise, explained. National Geographic Newsletters. Retrieved from https:// www.nationalgeographic.com/environment/globalwarming/sea-level-rise/ 